\title{
Kampanye Kreatif dalam Kontestasi Presidensial 2014
}

\author{
Bambang Arianto
}

\begin{abstract}
This article explaines about how the model appearances of creative campaign in presidential contestation 2014. This models more emphasizes the forms of creative campaign such as video, music, game application and visual design which are supported by the information technology advances. The model appearances of creative campaigns can be an effective ways of political communication to build the culture of participatory. The appearances of creative campaign also can encourage the change of behavior toward exticement politic.
\end{abstract}

\section{Keywords:}

Creative campaign; political communication; presidential contestation 2014; excitement political.

\begin{abstract}
Abstrak
Artikel ini menjelaskan tentang kemunculan model kampanye kreatif dalam kontestasi presidensial 2014, yang lebih mengedepankan unsur kreativitas dan seni. Adapun bentuk-bentuk kampanye kreatif seperti video, musik, aplikasi game dan desain visual yang didukung oleh kemajuan teknologi informasi, telah mampu melakukan transformasi dari model kampanye konvensional menuju kampanye modern. Kemunculan kampanye kreatif dapat menjadi saluran komunikasi politik yang efektif guna membangun budaya partisipatoris. Selain itu, kampanye kreatif sangat positif dalam mendorong perubahan perilaku politik kewargaan yang kemudian melahirkan politik kegembiraan.
\end{abstract}

\section{Kata kunci:}

kampanye kreatif, komunikasi politik, kontestasi presidensial 2014, politik kegembiraan.

\section{Pendahuluan}

Kampanye politik dalam kontestasi presidensial 2014 dapat dikatakan sebagai kampanye politik paling kreatif ${ }^{1}$ yang pernah ada dalam sejarah politik Indonesia. Pasalnya, studi ihwal kampanye pemilihan umum (Pemilu) Presiden di era Orde Lama dan

\footnotetext{
- Mahasiswa Pascasarjana Jurusan Politik dan Pemerintahan (JPP) Fisipol UGM, Yogyakarta Email: bulaksumur4@yahoo.com

1 http://www.republika.co.id/berita/pemilu/beritapemilu/14/07/23/n958et-pilpres-2014-hasilkan-banyak kampanye-kreatif
}

Orde Baru lebih banyak mengambarkan model kampanye pada pengerahan massa, seperti, pawai bersama, pidato politik, apel akbar, dan arak-arakan. Hal yang sama terjadi pada Pemilu 1977, yang merupakan pengulangan model kampanye Pemilu 1971. Model kampanye masih diisi oleh pidato politik para pejabat pusat di pelosok negeri dengan diselingi hiburan panggung artisartis kawakan. Artinya, pelibatan para figur publik seperti pejabat publik serta kaum pesohor sebagai bintang kampanye tampaknya menjadi ciri khas kampanye pada era tahun 
1970-an. ${ }^{2}$ Sejak Pemilu 1997, para kontestan memulai kampanye politik melalui internet, yang dimulai Partai Persatuan Pembangunan (PPP) dengan meluncurkan situs www.ppp.or.id. Kemudian diikuti, Golkar dengan www.golkar. co.id dan Partai Demokrasi Indonesia dengan www.banteng.org. ${ }^{3}$ Inilah yang kemudian turut mewarnai dinamika kampanye di Indonesia semenjak kehadiran teknologi informasi sekaligus menegaskan berkembangnya model kampanye. Hal itu dibenarkan oleh studi Scammel ${ }^{4}$ yang menyatakan Amerika Serikat (AS) memimpin perubahan gaya kampanye dengan cara-cara langsung, seperti dengan mempekerjakan sejumlah konsultan politik, serta berbagai upaya transfer pendidikan politik kepada para praktisi kampanye di luar Amerika Serikat.

Namun, dalam kontestasi presidensial 2014, fenomena kampanye Amerikanisasi dibantah dengan kehadiran fenomena relawan (voluntarisme) terutama yang berasal dari para pegiat, sekaligus menjadi titik awal kemunculan model kampanye kreatif. Kampanye kreatif yang digagas dapat dilihat ketika sosok Joko Widodo melakukan simulasi blusukan secara digital. Kampanye ini dinamakan Generasi Optimis (GO) Indonesia. Tujuan kampanye ini yakni untuk mengedepankan cara-cara yang positif dan kreatif, ketimbang hal-hal yang negatif. Cara-cara kampanye seperti yang dilakukan oleh para seniman asal Bandung. GO Indonesia juga mengajak generasi muda untuk memberi warna baru dalam pesta demokrasi melalui kampanye positif dengan nuansa yang sangat jenaka dan kreatif. Seluruh pengunjung dapat berkontribusi langsung

\footnotetext{
${ }^{2}$ Danial, Akhmad (2009). Iklan Politik, Modernisasi Kampanye Politik Pasca Orde Baru. Yogyakarta: LKIS.

3 T Hill, David \& Sen Krishna. (2005). The Internet in Indonesia \& New Democracy. London and New York: Routledge.

4 Margaret Scammel. (1997). The Wisdom of the[ War Room: U.S Campaigning and Americanization, Research Paper R-17, dalam The President and Fellows of Harvard College. Edisi April 1997, hlm 3.
}

melalui animasi, artikel, desain atau foto, game, meme, musik, komik, merchandise, video dan karya lain yang dapat didaftarkan melalui situs www.generasioptimis.org. ${ }^{5}$ Jika dilihat dari perkembangan trending topic terutama di media sosial, model kampanye kreatif lebih banyak menarik perhatian publik karena peran para pegiat seni dalam mendorong kemunculan kampanye kreatif berperan begitu besar. Jika ditelaah, keterlibatan para pegiat seni tersebut terinspirasi dari praktik apropriasi oleh gerakan Dadaisme, Marcel Duchamp, di Perancis pada tahun $1919 .{ }^{6}$ Gerakan ini memulai praktik apropriasi dengan berupaya menambah kumis pada reproduksi lukisan Monalisa karya Leonardo da Vinci di sehelai kartu pos bekas. Alhasil, praktik-praktik apropriasi dalam dunia seni inilah yang kemudian semakin populer hingga saat ini. Dalam kontestasi presidensial tahun 2014, praktik apropriasi dalam dunia seni dapat kita temukan dari sejumlah pegiat seni yang menjadi pengagas kampanye kreatif. Dalam konteks ini kampanye kreatif merupakan proses yang dirancang sebagai saluran komunikasi politik untuk mempengaruhi preferensi pemilih, dengan cara-cara yang unik, jenaka, plesetan dan humor untuk memberikan kesadaran kepada publik bahwa kontestasi politik menjadi hal yang menyenangkan dan kesuka-riaan. Beberapa jenis kampanye kreatif yang pernah hadir seperti, ilustrasi gambar "Tintin" ala Jokowi (desain grafis), musik, aplikasi games, hingga video yang menggunakan Youtube. Beberapa pegiat politik yang terlibat dalam kemunculan kampanye kreatif diantaranya, Hari Prasetyo, Yoga

\footnotetext{
5 Lihat, http://www.indopos.co.id/2014/06/kampanyekreatif-ala-jokowi.html.

6 Apropriasi adalah plesetan, parodi dan semacamnya terhadap berbagai karya seni populer. Seniman meminjam unsur-unsur dari suatu karya seni yang sudah jadi, lalu mengubah atau menambahnya sedemikian rupa, sehingga melahirkan karya baru. Lihat, Jokowi Bertemu Tintin, Koran Tempo, 26 Oktober 2014 hlm. 22
} 
Adhitrisna, dan kawan-kawan Demokreatif. ${ }^{7}$ Pegiat politik ini menciptakan sejumlah gambar Joko Widodo blusukan dengan gaya komik seri Petualangan "Tintin" karya Herge ${ }^{8}$ dengan motivasi awal ingin menjadikan kampanye cerdas dan kreatif yang dapat membendung beredarnya kampanye yang kontra-produktif dan membosankan. ${ }^{9}$ Pasalnya, selama ini publik seringkali disuguhi oleh berbagai model kampanye konvensional ${ }^{10}$ yang akhirnya menjadi sampah visual. Fenomena menjamurnya sampah visual iklan politik di ajang kampanye politik 2014 silam, cenderung menurunkan citra, kewibawaan, reputasi, dan nama elite politik maupun partai politik. Padahal, sejatinya alat peraga kampanye dapat menjadi bagian dari dekorasi kota yang artistik dan komunikatif. Bukan sebaliknya alat peraga kampanye justru mengokohkan dirinya menjadi teroris visual dengan menebarkan sampah visual iklan politik di ruang publik. Eksesnya ruang publik semakin diprivatisasi

\footnotetext{
Buku Demokreatif, lebih banyak memaparkan bagaimana pandangan relawan politik dan pegiat seni terhadap politik dan proses kelahiran gambargambar Jokowi Blusukan di berbagai daerah. Prasetyo, dkk. (2014). Demokreatif: Kisah Blusukan Jokowi. Jakarta Kepustakaan Populer Gramedia.

8 Menurut Hari Prast, jika dicermati sebetulnya sama sekali tidak menampilkan satu pun karakter Tintin milik Herge, termasuk tidak menuliskan nama Tintin. Namun, publik yang menghubungkan dengan Tintin. Hal itu dikarenakan beberapa hal yaitu karakter Jokowi yang memiliki kesamaan dengan karakter Tintin yang menggunakan gaya mengambar komik Eropa. Tetapi, sumber ide kampanye "Kisah Blusukan" kami tidak hanya berasal dari Tintin. Namun, diilhami oleh karakter Jokowi yang fenomenal, studi foto yang dilakukan termasuk, pengenalan terhadap berbagai kebudayaan dan keindahan yang ada di Indonesia, serta nilai-nilai idealisme yang kami percaya. Ide cover komik Tintin telah bertransformasi menjadi sebuah kampanye politik yang positif, menghibur, banyak membawa pesan, serta dapat bertransformasi menjadi pengingat akan indahnya Bhinneka Tunggal Ika.

9 Wawancara dengan salah satu inisiator relawan Demokratif, Hari Prasetyo, melalui facebook, 11 Oktober 2015. Pukul 16.00 WIB.

${ }^{10}$ Kampanye konvensional, menurut penulis terdiri dari kampanye positif (positive campaign), kampanye negatif (negative campaign) dan kampanye hitam (black campaign).
}

jadi milik merek dagang kontestasi para elit politisi (Tinarbuko, 2013). Dalam perspektif Komunitas Reresik Sampah Visual, sampah visual iklan politik dipahami sebagai aktivitas pemasangan iklan politik, menggunakan media luar ruang yang penempatannya tak sesuai peruntukannya. Keberadaannya pun cenderung ilegal. Hal itu diperparah kelakuan menyimpang dari penebar sampah visual iklan politik yang tak mau mengurus izin dan membayar pajak reklame untuk kategori alat peraga kampanye politik. ${ }^{11}$

Dalam kontestasi presidensial 2014 banyak ditemui materi kampanye yang mengarah kepada hal-hal yang tidak substansial dan cenderung menyakitkan hati pendukung masing-masing sehingga berdampak menurunkan daya tarik pemilih, terutama pemilih muda. Ironisnya, model kampanye konvensional ini seringkali menggiring publik kepada dua hal. Pertama, materi yang disampaikan dalam kampanye akan lebih mengedepankan keunggulan calon yang kita dukung dengan pemaparan program yang membosankan bagi sebagian orang. Kedua, menjelek-jelekan kandidat politik atau calon presiden lain yang berakhir fitnah hingga pembunuhan karakter. Akhirnya, model kampanye tersebut cenderung membuat publik enggan untuk berpartisipasi aktif dalam politik. Meski demikian, semenjak kehadiran relawan politik ${ }^{12}$ yang kemudian mendorong hadirnya kampanye kreatif dapat menjadi fenomena baru dalam mengulas tipologi sejarah kampanye politik di Indonesia. Kehadiran kampanye kreatif lahir dari gagasan kreatif para relawan politik. Menurut Savirani (2015) relawan politik dapat dikategorikan menjadi tiga kelompok. Pertama, relawan yang berasal dari mantan aktivis yang terlibat dalam kisaran tahun 1990-

\footnotetext{
${ }^{11}$ Lihat, Tinarbuka, Sumbo (2013). Sampah Visual Iklan Politik. Kompas, 14 September 2013.

${ }^{12}$ Arianto, Bambang (2014). Fenomena Relawan Politik Dalam Kontestasi Presidensial 2014. Jurnal Ilmu Sosial dan Ilmu Politik. Vol. 18, No. 2 Edisi November.
} 
an atau lebih dikenal sebagai aktivis gerakan pro-demokrasi untuk menggulingkan rezim Soeharto. Kedua, adalah aktivis dari berbagai organisasi non-pemerintah mulai dari gerakan anti-korupsi, petani dan kelompok masyarakat adat. Ketiga, adalah seniman dan orangorang di sektor kreatif. Kelompok pertama dan kedua memiliki agenda politik, namun sayangnya tidak memiliki massa yang jelas. Berbeda dengan kelompok ketiga yang tidak memiliki agenda politik tetapi memiliki banyak jejaring massa dari semua lapisan masyarakat. Hal itu disebabkan bekal popularitas yang dimilik oleh para artis dan seniman sehingga dapat menarik lebih banyak pendukung dan pengikut. ${ }^{13}$ Artinya, kehadiran relawan politik dapat membantah penilaian adanya paradoks besar dalam sejarah politik elektoral Indonesia, khususnya soal menurunnya tingkat partisipasi politik publik. Apalagi, jika dilihat dari beberapa pemilihan umum (Pemilu) ke Pemilu berikutnya di Indonesia, jumlah golongan putih (golput $)^{14}$ semakin meningkat. Pada Pemilu 2009 silam golput mencapai puncaknya. ${ }^{15}$ Gambaran fluktuasi golput dari Pemilu ke Pemilu menegaskan bahwa publik sudah cukup pesimis dengan figur-figur yang diusung oleh partai politik untuk memperbaiki kondisi bangsa. Apalagi, pasca reformasi preferensi politik Indonesia telah beralih dari partai politik (parpol) menuju figur. Artinya, figur dan ketokohan sangat berpengaruh kuat terhadap kultur politik Indonesia. Hal ini didasari oleh perilaku pemilih Indonesia yang kerap dipengaruhi elektabilitas figure. Dalam kontestasi pemilihan legislatif 2014, tidak semua calon anggota legislatif (caleg) dari kalangan artis yang dapat lolos meraih suara

\footnotetext{
${ }^{13} \mathrm{http}: / /$ theconversation.com/jokowis-supporters-arestarting-to-doubt-the-indonesian-obama-37843

${ }^{14}$ Nyarwi. (2009). Golput Pasca Orde Baru: Merekonstruksi Ulang Dua Perspektif. Jurnal Ilmu Sosial dan Ilmu Politik. Vol. 12 Nomor 3 Edisi Maret.

${ }^{15}$ http://politik.news.viva.co.id/news/read/503322-angkagolput-menurun-di-pemilu-2014.
}

untuk duduk di DPR RI. Pasalnya popularitas tidak sama dengan elektabilitas. Kalangan artis memiliki popularitas yang cukup tetapi belum tentu memiliki elektabilitas dihadapan publik. Hanya lima belas artis lolos menjadi anggota DPR RI periode 2014-2019 yang tersebar di sejumlah partai politik (parpol) dan Daerah Pemilihan (Dapil diantaranya; Okky Asokawati (PPP). Tantowi Yahya (Golkar). Junico BP Siahaan atau Nico Siahaan (PDI Perjuangan). Rachel Maryam Sayidina (Gerindra). Dede Yusuf Macan Effendi (Demokrat). Desi Ratna Sari (PAN). Primus Yustisio (PAN). Krisna Mukti (PKB). Rieke Diah Pitaloka (PDI Perjuangan). Jamal Mirdad (Gerindra). Anang Hermansyah (PAN). Moreno Suprapto (Gerindra).Venna Melinda (Demokrat). Eko Hendro Purnomo alias Eko Patrio dan Lucky Hakim (PAN). Hal itu mengonfirmasi survei Pol-Tracking Institute yang dirilis di Jakarta (19/12/2013), caleg dari kalangan artis hanya disetujui oleh 18,7 persen responden. Sebanyak 68,44 persen responden mengaku tidak setuju dan tidak akan memilih caleg artis. Sisanya 15,85 persen mengaku tidak tahu atau tidak menjawab. Survei ini dilakukan dengan metode wawancara tatap muka menggunakan kuesioner. Jumlah sampel adalah 2.010 warga di semua provinsi di Indonesia yang telah berusia 17 tahun dan bukan anggota TNI/Polri ${ }^{16}$ yang nantinya akan berkorelasi positif pada elektabilitas parpol. Pemilih kemudian akan lebih memilih partai bukan karena daya tarik partai dan programnya, melainkan lebih pada ketertarikan pada sosok figur yang diusung. ${ }^{17}$

\footnotetext{
${ }^{16}$ http://politik.news.viva.co.id/news/read/504521-15artis-lolos-jadi-anggota-dpr-ri-2014-2019.

17 Ada beberapa faktor yang mempengaruhi preferensi pemilih pemula dalam kontestasi presidensial 2014, seperti gaya komunikasi politik Joko Widodo, yang tampil sederhana dan mudah dipahami sehingga berkesan sangat dekat dengan rakyat. Kekuatan yang paling menonjol dalam kepemimpinan Jokowi bukan teknokrasinya, melainkan energi positifnya, yaitu nilai keterbukaan, kesederhanaan, dan kekuatannya dalam menginspirasi rakyat. Lihat, Arianto, Bambang. (2015) Jokowisme. Harian Bernas. Edisi 12 Maret.
} 
Hal ini semakin menegaskan menguatnya fenomena personalisasi politik dalam kultur politik Indonesia. Fenomena personalisasi politik sangat dipengaruhi oleh watak dari rezim yang otoritarian, karena politik seringkali diartikan sebagai persoalan personal ketimbang persoalan organisasi. Eksesnya, personalisasi politik mau tidak mau menjangkiti watak kolektif partai politik. ${ }^{18}$ Parpol tidak lagi berpikir soal pengorganisasian ide dan pergulatan di bawah haluan ideologi tertentu, tetapi hanya berpikir bagaimana merekrut figur untuk meningkatkan dukungan kolektif publik. Wajah demokrasi Indonesia inilah yang menjadi penyebab utama terputusnya fungsi linkage baik dari publik kepada negara. Pasalnya, berbagai saluran partisipator seringkali tergantikan dengan hegemoni para patron-yang dengan mudahnya membeli suara dan kepercayaan rakyat. Selain itu, personalisasi politik juga memiliki sisi negatif yakni dapat mengubah gelanggang elektoral menjadi kompetisi antar figur yang kemudian cenderung melahirkan kampanye negatif dan hitam.

Hakikat kampanye merupakan bentuk komunikasi politik dalam upaya membujuk pemilih (voter) agar mendapatkan dukungan dari publik. Oleh karena itu, di balik keramaian massa dengan berbagai atribut, kampanye politik tetap miskin dari gagasan. Akhirnya, keramaian ide, gagasan, dan visi-misi terasa mulai berpindah ke ruang-ruang maya. Hal itu ditandai peran teknologi informasi yang telah mampu melahirkan media baru yang mengacu pada konvergensi antara teknologi audio atau video dengan World Wide Web (Dominick, Messere \& Sherman, 2004). Sehingga arena diskusi, perdebatan, hingga saling tuduh secara bebas terjadi di ranah media sosial. Bagi kalangan yang terdidik, kampanye menggunakan teknologi informasi lebih efektif dan efisien ketimbang menggunakan alat peraga luar ruangan seperti

${ }_{18}$ Adian, Donny Gahral. (2012). Personalisasi Politik. Kompas. Edisi 27 September. hlm 6 baliho atau spanduk. Sebab, pemilih cenderung tidak lagi percaya dengan muatan baliho atau spanduk, tetapi lebih percaya pada perkataan teman atau koleganya di media sosial.

Dalam leksikon ilmu politik memang belum dikenal istilah kampanye kreatif, sebab selama ini hanya dikenal istilah kampanye positif (positive campaign), kampanye negatif (negative campaign), dan kampanye hitam (black campaign). Adapun kampanye positif, lebih mengedepankan kata-kata hiperbolis yang bertujuan mengenalkan calon pemimpin atau presiden secara pribadi, baik program kerja dan visi misinya. Kampanye negatif, yakni kampanye yang memberikan berbagai informasi negatif berisikan pesan-pesan negatif terhadap lawan politik dengan berdasarkan fakta yang jujur dan relevan, terutama soal kapasitas, kapabilitas, skandal dan rejam jejak kandidat politik yang pernah terjadi. ${ }^{19}$ Tetapi, ketiga model kampanye tersebut tidak memiliki konsep yang tepat pada sasaran yang dibidik, karena materi kampanye lebih terkesan monoton. Padahal, kampanye sejatinya dapat diterjemahkan dari tema besar yang serba elitis ke tema-tema yang dapat lebih menarik dan menghibur. Tentu saja hal ini agar berbagai program kerja yang ditawarkan dalam kampanye dapat menarik dan menjadi bagian dalam nalar politik pemilih.

Maklum diketahui bahwa preferensi pemilih terhadap kontestan telah ada jauhjauh hari sebelum kampanye pemilu dimulai. Sehingga, siapa yang akan memenangkan pemilihan umum dapat dengan mudah ditentukan sebelum pemilihan umum

\footnotetext{
${ }^{19}$ Kampanye negatif berbeda dengan kampanye hitam, sebab kampanye negatif didukung dengan fakta empiris yang dapat dibuktikan. Survei yang dilakukan oleh Lingkaran Survei Indonesia membuktikan bahwa 64.2 persen publik menyatakan kampanye negatif penting bagi mereka sebagai pembelajaran politik untuk mengetahui kekurangan dari kandidat atau partai politik. Sedangkan sebanyak 20.5 persen publik menyatakan tidak setuju atau tidak penting kampanye negatif tersebut. Dan sebanyak 12.5 persen menyatakan sikap netral. Lihat, http://1si.co.id/lsi/2014/04/02/ kampanye-negatif-dan-prediksi-hasil-pileg-2014.
} 
dilaksanakan. ${ }^{20} \mathrm{Hal}$ ini menunjukkan bahwa pemilih mengevaluasi layak atau tidaknya suatu kandidat tidak hanya terbatas pada rekam jejak melainkan juga berdasarkan pada model kampanye pemilu yang ditawarkan. Artinya, jika hanya menghandalkan kampanye konvensional, dipercaya akan sulit mempengaruhi preferensi pemilih. Berbeda, jika menggunakan model kampanye kreatif yang lebih mengedepankan kreativitas dipercaya lebih mudah menarik simpati pemilih nonkader dan non-partisan (eksternal).

Peran dan partisipasi publik terutama yang memiliki jiwa-jiwa kreatif dapat menjadi aktor penggerak utama dalam melahirkan kampanye yang menarik, agar tercipta kegembiraan politik. Kegembiraan politik adalah perayaan demokrasi yang menyenangkan, dan penuh kesuka-riaan, guna memperjuangkan nilainilai baru. Nilai-nilai baru yang ditujukan sebagai jalan pencerahan bagi upaya mengarahkan masyarakat untuk lebih baik dengan penuh pengorbanan, bukan dengan kalkulasi untung rugi. Pendek kata, dengan adanya perubahan rekonfigurasi dinamika transformasi model kampanye dalam ranah politik yang kemudian mengajak kita pada dua pertanyaan; Bagaimana peran kampanye kreatif sebagai saluran komunikasi politik dalam upaya melembagakan partisipatorisme? Bagaimana peran kampanye kreatif dalam membangun kegembiraan politik? Batasan dalam penelitian ini hanya seputar peran dan implikasi kampanye kreatif dalam upaya membangun kegembiraan politik. ${ }^{21}$

\section{Kampanye Kreatif sebagai Saluran Komunikasi Politik}

Kampanye politik idealnya ditujukan untuk menarik simpati publik agar dikemudian

\footnotetext{
${ }^{20}$ https://www.rochester.edu/College/faculty/mperess/ ada2007/Gelman_King.pdf.

${ }^{21}$ Dalam konteks ini kegembiraan ditandai dengan kemunculan partisipasi politik dari publik itu sendiri, bukan dari tawaran uang atau politik balas jasa.
}

hari dapat menentukan pilihan terhadap kandidat politik dan partai politik. Tetapi, kesuksesan dalam suatu kampanye politik tentulah tidak lepas dari faktor-faktor yang menunjang keberhasilannya terutama peranan teknologi informasi pada dekade terakhir sangat menentukan. Menurut Lock dan Harris (1996) dalam kampanye politik terkait erat dengan pembentukan image politik. ${ }^{22}$ Dalam kampanye politik terdapat dua hubungan yang akan dibangun, yaitu internal dan eksternal. Hubungan internal adalah suatu proses antara anggota-anggota partai dan pendukung untuk memperkuat ikatan ideologis dan identitas di antara partai dan konstituen. Sementara hubungan eksternal dilakukan untuk mengkomunikasikan image yang akan dibangun kepada pihak luar partai, termasuk media massa dan masyarakat secara luas. Oleh sebab itu, image politik tersebut perlu didukung oleh konsistensi aktivitas politik jangka panjang, termasuk oleh model kampanye yang dilakukan secara permanen dan tidak terbatas pada menjelang pemilu saja. Selama ini banyak pihak yang menyamaratakan pengertian kampanye politik dan kampanye Pemilu. Padahal, jika ditelusuri kampanye politik lebih luas dari kampanye pemilu. Kampanye politik merupakan suatu proses jangka panjang yang menuntut konsistensi dan kontinuitas dari partai politik. ${ }^{23}$ Sedangkan kampanye pemilu hanya dilakukan menjelang pemungutan suara sehingga memiliki beberapa kelemahan. Ada beberapa kelemahan dari kampanye Pemilu, diantaranya; Pertama, interaksi politik antara partai politik dan publik seolah-olah hanya

${ }^{22}$ Image politik mengandung objektivitas dan subjektivitas secara beramaan. Dalam image politik terdapat hal-hal yang dapat dilogiskan, yakni bahasa image adalah konstruksi empiris dan terbukti di lapangan. Ketika partai tersebut telah memiliki image peduli terhadap wong cilik, maka partai tersebut telah melakukan serangkaian aktivitas keberpihakan terhadap masyarakat kecil. Lihat, Firmanzah, Marketing Politik, Antara Pemahaman dan Realita. hlm 239

${ }^{23}$ Blumenthal, S. The Permanent Campaign. (1982). New York. Simon and Schuster. hlm 12-25. 
terjadi pada periode tertentu saja. Kedua, kampanye merupakan proses komunikasi politik dialogis antar partai politik dengan publik. Jika kampanye hanya dilakukan sebatas Pemilu dikhawatirkan tidak akan tercipta kesamaan pemahaman politik diantara keduanya. Ketiga, dalam kampanye Pemilu, publik seringkali diartikan sebagai dan sebatas pengumpul suara dan hanya menjadi objek dari partai politik. Keempat, kampanye merupakan bagian dari pendidikan politik. Artinya, jika kampanye hanya sebatas Pemilu saja, maka proses transfer pendidikan politik kepada publik tidak berjalan secara komprehensif, sehingga publik hanya disuguhi oleh banyak hal yang bersifat parsial dan insidental.

Menurut Norris (2000) kampanye politik adalah suatu proses komunikasi politik, di mana partai politik atau konstituen individu berusaha mengkomunikasikan ideologi ataupun program kerja yang mereka tawarkan. Baik, soal warna bendera, simbol partai hingga berbagai bentuk sosialisasi melalui pidato politik. Dengan dipenuhi oleh jargon-jargon politik, termasuk kata-kata yang hiperbolis membuat kampanye memiliki makna lebih luas lagi. Bila kampanye politik dapat menjadi saluran komunikasi politik hal itu menandai pemanfaatan ruang publik yang optimal. Menurut Jurgen Habermas (1989) pemanfaatan ruang publik secara optimal ditandai dengan adanya kondisi demokratis dalam skala luas yang ditandai berfungsinya ruang publik untuk mempertemukan kehidupan politis dan sosial, di luar lembaga-lembaga negara yang formal. Sifat dari ruang publik itu cair dan terbuka, di mana para aktornya adalah masyarakat itu sendiri yang berpartisipasi dalam diseminasi, multiplikasi, dan proteksi ruang publik. ${ }^{24}$

Dalam konteks kampanye politik 2014, peran teknologi informasi terutama media sosial dapat menjadi ruang publik yang seperti

\footnotetext{
${ }^{24}$ Hardiman, F Budi. (2010). Komersialisasi Ruang Publik Menurut Hannah Arendt dan Jurgen Habermas. Yogyakarta: Penerbit Kanisius.
}

diimpikan oleh Jurgen Habermas. Pasalnya, perkembangan teknologi informasi di Indonesia memang telah berhasil menggandakan jumlah ruang diskusi publik. Pasalnya, teknologi informasi yang melahirkan ruang maya punya memiliki peran strategis sebagai ruang publik, sejauh publik di dalamnya memang sudah sejak awal punya komitmen untuk terlibat dengan persoalan-persoalan dunia nyata yang mengancam kebaikan bersama. ${ }^{25} \mathrm{Hal}$ inilah yang kemudian mendorong adanya keinginan publik untuk menghadirkan model kampanye dengan penyajian yang menarik sebagai saluran komunikasi politik. Hal itu tampak sejak kemunculan fenomena penggunaan Avatar I stand on the Right Side di media sosial, yang diikuti oleh kubu Prabowo-Hatta dengan versi, warna dan peletakan yang kontras, mampu menjadi saluran komunikasi politik yang dapat menarik partisipasi publik. Artinya, secara tidak langsung keberpihakan seseorang di media sosial menjadi lebih mudah terpetakan berkat penggunaan avatar ini. Menariknya, fenomena kampanye I Stand on The Right Side ${ }^{26}$ meroket di posisi teratas meninggalkan semua jenis kampanye di dunia. Paling sedikit ada 26.673 dukungan dan tiap detiknya terus bertambah, yang ditujukan mendukung calon presiden nomor urut dua dengan memasang pita yang dibuat di Twibbon.com. Twibbon adalah

\footnotetext{
${ }^{25}$ Supelli, Karlina. (2010) Ruang Publik Dunia Maya, Melacak Partisipasi Demokratis Dari Polis sampai Cyberspace. Yogyakarta: Penerbit Kanisius. hlm 344

${ }^{26}$ Entah siapa yang sebenarnya memulai, namun di akun Facebook milik DPP PDI-Perjuangan (facebook. com/DPP.PDI.Perjuangan), disebutkan pekerja seni Joko Anwar dan Ernest Prakarsa yang pertama memulai menggunakan avatar "I Stand on The Right Side". Format avatar dukungan nomor dua ini di linimasa Twitter disebutkan dibuat pertama kali oleh akun Twitter @monstreza. Menariknya, banyak yang menyediakan berbagai alat bantu untuk bisa membuat avatar pita dukungan. Paling besar dari situs web Twibbon.com, yang spesialis menyediakan alat bantu kampanye menggunakan pita. Ternyata, kampanye "I Stand on The Right Side" ini di Twibbon diinisiasi oleh Thomas Harjanto dengan akunnya. Lihat, http://www. endonesia.com/2014/06/fenomena-i-stand-on-rightside-perang.html?showComment=1420936581930.
} 
sebuah aplikasi kecil yang diciptakan untuk meningkatkan dukungan, daya tarik, dan kegunaan media sosial. Twibbon adalah alat untuk menggalang dukungan untuk sesuatu, baik itu perusahaan, gerakan, organisasi, atau apapun. Pada awalnya, Twibbon akan menampilkan bentuk dukungan anda dengan menempelkan sebuah logo dari sesuatu yang anda dukung, misalkan organisasi anda, pada foto profil. Anda akan diminta mengunggah logo tersebut, mengubah ukurannya menjadi sekitar 200 x 200 piksel, dan menempelkannya pada foto profil anda di Facebook atau Twitter. Di samping itu, Twibbon juga terintegrasi dengan Twitter, di mana melalui Twibbon, anda dapat mengirimkan pesan tweet yang berisi dukungan anda terhadap organisasi atau perusahaan. Twibbon adalah alat yang cocok untuk digunakan pada musim-musim kampanye atau perilisan produk atau organisasi baru karena melalui Twibbon, anda dapat menggalang perhatian dan dukungan masyarakat ${ }^{27}$

\section{Gambar 1. Avatar dari kedua pasangan calon presiden}

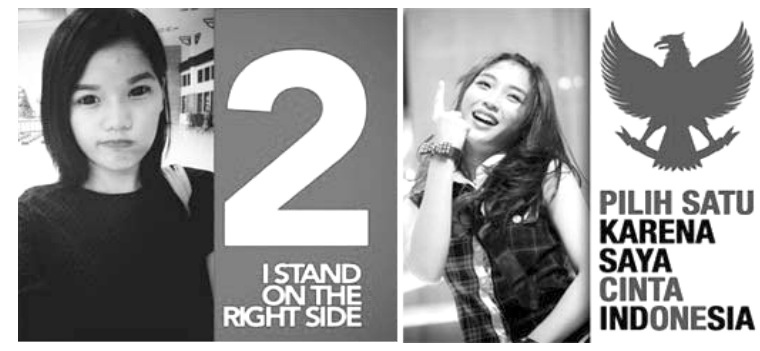

Sumber : http://www.endonesia.com/2014

Hal yang sama juga terjadi pada salah satu jenis kampanye kreatif yang mengunggulkan ilustrasi. ${ }^{28}$ Melalui tema ilustrasi "Kisah

\footnotetext{
${ }^{27}$ http://www.fanspage-id.com/2012/10/menggalangdukungan-di-media-sosial.html.

${ }^{28}$ Kampanye kreatif memang banyak menggunakan gaya ilustrasi disebabkan beberapa hal; Pertama, teknik ilustrasi merupakan kemampuan pribadi seorang yang bisa dilakukan secara mandiri. Tidak memerlukan banyak biaya produksi, serta tidak memerlukan alat yang mahal, dan tidak membutuhkan orang banyak. Kedua, teknik ilustrasi bisa menjadi ajakan halus bagi
}

Blusukan" dengan dilengkapi oleh karena memiliki teknik Ommision and Suggestion para relawan politik berusaha mendorong interaksi dan keterlibatan publik. Caranya, para relawan kreatif mengedarkan ilustrasi dengan versi bolong yakni versi Do It Yourself dari versi "Panen Raya", yang mana di bidang tengahnya dibuat bidang bolong. Kemudian, para relawan mendorong agar orang yang melihat ilustrasi ini dapat bebas mengisi dengan gambar daerahnya masing-masing atau apa saja. Sehingga, setiap orang dapat dengan mudah menginginkan kisah blusukan berasal dari masing-masing, karena publik didorong untuk bisa mengisi sendiri gambarnya.

\section{Gambar 2. Contoh ilustrasi dengan teknik Ommision and Suggestion}

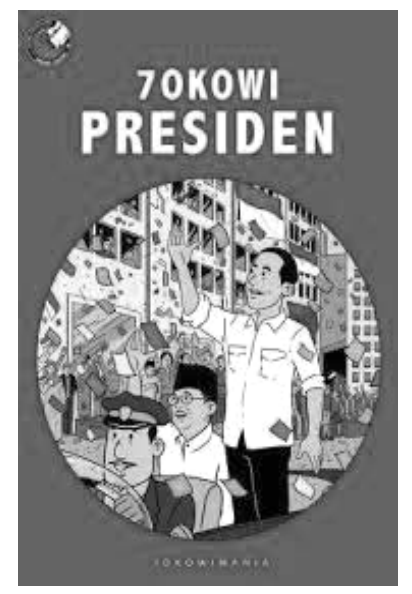

Sumber : www. gulunglenganbajumu.com

Ilustrasi yang ditampilkan lebih mengikuti isu aktual yang berkembang pada masa kampanye. Persebaran "Kisah Blusukan" 29

orang-orang kreatif atau bahkan siapapun untuk turut berkarya. Ketiga, teknik ilustrasi tidak mudah ditiru dan dipalsukan. Sebab, selama ini derasnya peredaran kampanye fitnah, banyak oknum yang menggunakan kemampuan photoshop untuk membolak-balik materi kampanye. Bahkan dengan kemampuan editing sederhana berita Youtube saja bisa dipotong.

${ }^{29}$ Keunggulan kampanye Kisah Blusukan selain dapat mencuri dan memancing interaksi publik dengan persebarannya di media sosial juga memancing kehadiran para relawan kreatif dalam kontestasi politik. Lihat, Adhistrisna, Yoga, dkk (2015). Kampanye 2.0 - 
yang didukung oleh situs gulunglenganbajumu. $\mathrm{com}^{30}$ terbukti mampu mendapat respons publik. Hanya seminggu setelah beroperasi (13/06), terhitung terkumpul $>7.500$ unique visitors, >203.500 hits, dengan total bandwith 20 GB yang digunakan pengunjung. Puncak kunjungan ke situs ini terjadi pada hari Minggu (15/06). Tercatat $>4.700$ unique visitors, jumlah hits $>187.000$ dan $>14$ GB yang diunduh dalam sehari. Pengunjung situs ini tidak hanya dari dalam negeri, tetapi juga yang berada di luar negeri. Tampak dari toal $>8.700$ hits dari Amerika, $>7.300$ hits dari Inggris, dan $>6.200$ hits dari Singapura (Prasetyo, 2014). Fenomena I Stand on The Right Side dan kehadiran ilustrasi "Kisah Blusukan" menjadi dua alat bukti bahwa kampanye kreatif dapat menjadi saluran komunikasi politik yang sangat efektif. Tanpa disadari fenomena ini mampu menjadi model kampanye kreatif yang berkonsep dan tepat pada target yang dibidik, terutama dapat langsung penetratif ke simpul-simpul pemilih. Fenomena ini dapat menandai hadirnya siberaktivisme yaitu konsep yang memotret lahirnya berbagai gerakan masyarakat sipil (Adiputra, 2014).

Ada beberapa kelebihan yang dihasilkan oleh kampanye kreatif, diantaranya; Pertama, dapat mengidentifikasi masalah faktual yang dirasakan, sebab prasyarat utama kampanye dapat dikatakan sukses bila dapat berorientasi pada isu (issues-oriented) bukan semata berorientasi pada citra (imageoriented). Sebab, bukan saatnya lagi kampanye dapat menawarkan solusi imajiner yang

Voter Generated Content. Jakarta: Kepustakaan Populer Gramedia (KPG), hlm 108.

${ }^{30}$ Gerakan Gulung Lengan Bajumu adalah ekspresi kami agar masyarakat luas turut aktif dalam mendukung Jokowi menjadi Presiden RI di Pemilu 2014 yang damai, cerdas, dan kreatif. Gerakan ini diawali setelah pertemuan kami dengan kelompok relawan pendukung Jokowi, JO-MAN (Jokowimania) dan kesediaan kami membantu kawan-kawan JO-MAN untuk menyediakan desain-desain yang dapat digunakan untuk berkampanye. Lihat, http://gulunglenganbajumu. com. abstrak, apalagi yang tidak memiliki basis pemecahan masalah (problem solving). Kedua, memiliki pengelolaan yang cukup baik, terutama dari sisi perancangan, pelaksanaan hingga evaluasi, sehingga dengan mudah mengidentifikasi karakteristik pemilih untuk merumuskan pesan komunikasi politik yang tepat. Seluruh isi program kampanye (campaign content) dapat diarahkan untuk membekali dan memengaruhi aspek pengetahuan, sikap, serta keterampilan pemilih sebagai prasyarat utama perubahan perilaku pemilih (voting behavior). Apalagi, setiap warga negara mempunyai kepentingan dan preferensi tentang siapa yang seharusnya memerintah termasuk perihal kebijakan publik yang dibuat oleh aparatur pemerintah. Dalam pengertian ini partisipasi politik terkait dengan rasionalitas dan responsiveness (Mujani, 2007: 254). ${ }^{31}$

Dengan demikian berarti perincian program kampanye dapat menarik dan menjadi bagian utuh perubahan kesadaran pemilih. Artinya, kampanye kreatif yang didukung oleh penggunaan media baru ${ }^{32}$ dapat menjadi saluran komunikasi politik yang tidak hanya terfokus pada upaya menjual janji palsu atau pembohongan publik, melainkan mampu menjadi saluran komunikasi politik yang dapat lebih memahami kondisi pemilih secara faktual dan elementer yang dapat menjadi sebuah deklarasi komitmen untuk melakukan halhal terbaik guna menarik partisipasi publik seluas-luasnya. Hal ini yang menegaskan bahwa kampanye kreatif telah mampu menjadi wahana bagi perbaikan kesadaran tentang hakhak politik pemilih yang kemudian menjadi arena pembelajaran politik bagi pemilih.

\footnotetext{
${ }^{31}$ Mujani, Saiful. (2007). Muslim Demokrat, Islam, Budaya Demokrasi, dan Partisipasi Politi di Indonesia Pasca Orde Baru. Jakarta: Gramedia Pustaka Utama.

32 Sembiring,Bellisa G. (2014). Media Baru dan Kampanye Politik: Studi Kasus Strategi Komunikasi Politik menggunakan Media Baru oleh Jokowi Ahok Social Media Volunteers (Jasmev) Pada Pilkada DKI Jakarta Bulan Agustus September 2012. Skripsi Jurusan Ilmu Komunikasi UGM. Tidak Dipublikasikan, UGM Yogyakarta.
} 


\section{Kampanye Kreatif dan Teknologi Informasi}

Peranan teknologi informasi akhirnya telah mampu melahirkan media baru yang mengacu pada konvergensi antara teknologi audio atau video dengan World Wide Web (Dominick, Messere \& Sherman, 2004). Itu mengapa, peran teknologi informasi cukup signifikan dalam mendorong kemunculan kampanye kreatif terutama di media sosial dan teknologi Youtube. Media sosial tidak lagi berlaku one man one vote, tetapi satu orang dapat memiliki kekuatan setara puluhan, ratusan, hingga ribuan lebih orang. Inilah kelebihan yang dimiliki media sosial, efektif sebagai sarana pertukaran ide dan gagasan. Ironisnya, dekade terakhir pertukaran ide dan gagasan dimedia sosial sering disalah artikan menjadi alat untuk menuai kebencian dan permusuhan yang mengakibatkan ruang publik semakin agonistik. Hal itu ditandai oleh kemunculan fenomena Jonru, yang sebelumnya menjadi pegiat budaya membaca dan menulis, yang identik dengan kedalaman dan kesunyian, bergeser menjadi aktivis media sosial yang lebih banyak menawarkan suasana hingar tak berkesudahan. Padahal, Jumlah like di fanspage FB-nya sampai 400 ribu akun, dan follower di Twitter-nya hampir 50 ribu sampai dengan Rabu kemarin. Jumlah "umat" sebanyak itu sebenarnya bisa menjadi sebuah potensi besar untuk semakin memasifkan gerakan membaca dan menulis yang ia lakukan. Tapi rupanya Fanspage dan akun Twitter-nya sebagian besar, kini membicangkan persoalan politik. Perkembangan literasi di Indonesia tidak lagi dibicarakan. Fanspage dan Twitter Jonru kini justru menegasi esensi literasi. Alhasil, pergeseran ini kemudian menggiring para pengikut Jonru ke ranah illeteracy sangat besar. Artinya, media sosial bisa jadi membuat orang berbelok arah dari soft politics (literasi, budaya) ke hard politics (partai-kekuasaan). ${ }^{33}$

\footnotetext{
${ }^{33}$ Irkham, Agus M (2014). Jonru. Koran Tempo. Edisi 23 November.
}

Dengan cara kerja seperti multi-level marketing, efektivitas media sosial dapat menjadi kekuatan dan sarana komunikasi politik di mana setiap individu dapat saling memengaruhi. Jika proses komunikasi politik dalam kampanye kreatif dapat bersinergi dengan media sosial, maka hal itu akan dapat menjadi salah satu faktor kunci untuk meningkatkan partisipasi publik dalam setiap ritual kontestasi politik.

Meski demikian, belum ada penelitian yang dapat mengukur efektivitas kampanye di media sosial. Tetapi, sebagai perbandingan, dalam Mass Communication and Societ ${ }^{34}$ disebutkan bahwa perhatian terhadap kampanye di media sosial pada pemilihan presiden Amerika Serikat tahun 2008 cukup signifikan. Dalam penelitian ini ditemui, ada 27 persen pemilih dewasa di bawah umur 30 tahun mendapatkan materi kampanye dari media sosial. Sedangkan pemilih berumur 30-39 tahun hanya 4 persen, dan lebih dari 40 tahun hanya 1 persen. Artinya, media sosial sangat tepat sebagai medium untuk membidik para kawula muda. ${ }^{35}$ Itu mengapa, dalam kontestasi presidensial 2014, kedua pasangan calon presiden sama-sama menggunakan media sosial sebagai alat komunikasi politik. Berikut beberapa contoh akun media sosial yakni Facebook dan Twitter oleh pasangan Prabowo Subianto Hatta Rajasa dan Joko Widodo - Jusuf Kalla.

Dalam konteks ini penggunaan media sosial terutama Facebook, didapati informasi bahwa jumlah penggemar Prabowo di Facebook mencapai 7.425 .440 orang. ${ }^{36}$ Linimasa Facebook Prabowo banyak diisi fotonya ketika

\footnotetext{
${ }^{34}$ Kushin, Matthew James \& Yamamoto, Masahiro (2010). Did Social Media Really Matter? College Students' Use of Online Media and Political Decision Making in the 2008 Election. Mass Communication and Society, Volume 13, Issue 5, 2010.

${ }^{35} \mathrm{~h} \mathrm{t} \mathrm{t} \mathrm{p://teknologi.metrotvnew} \mathrm{s.com} \mathrm{/}$ $\mathrm{read} / 2014 / 07 / 04 / 261288 /$ peran-media-sosial-dalamkampanye-politik.

${ }^{36}$ Hasil ini menunjukan dukungan dari tim sukses maupun relawan politik dari kubu Prabowo - Hatta. Tetapi tidak menutup kemungkinan bagian dari rekayasa tim teknologi informasi. Oleh timses Prabowo Hatta.
} 


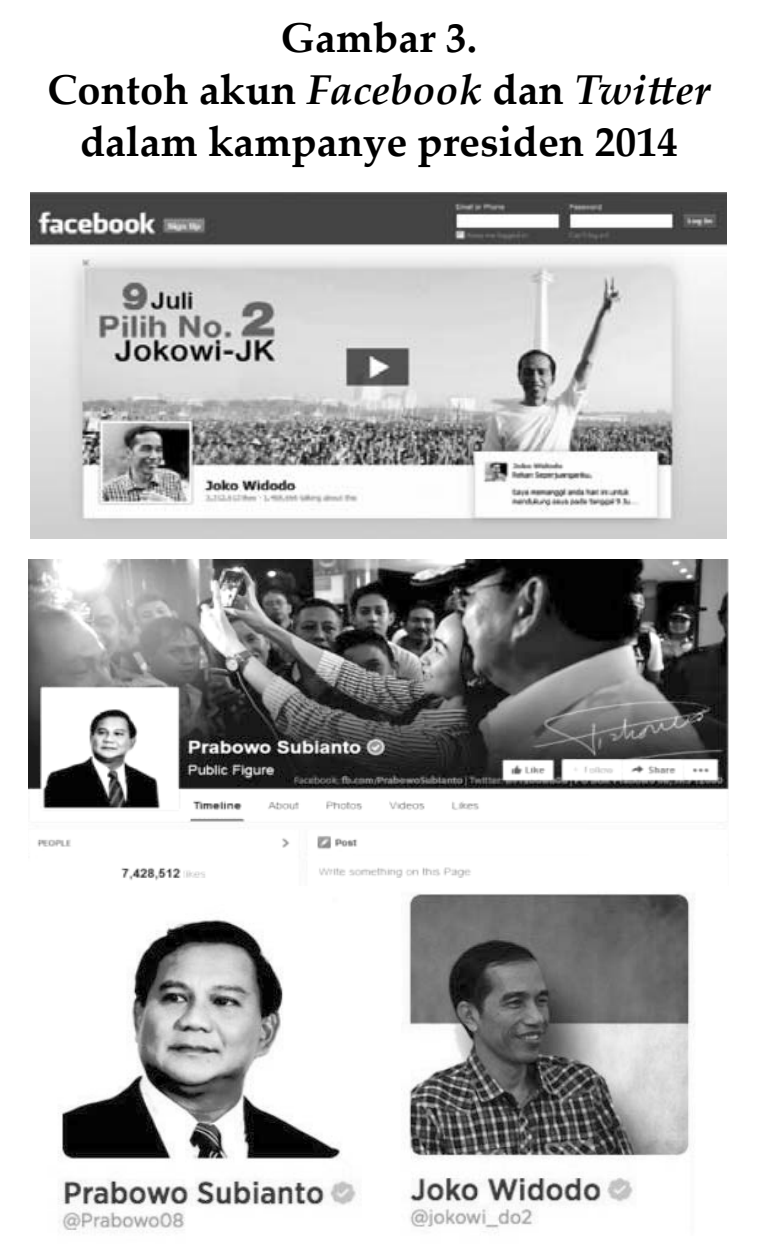

Sumber: http://teknologi.metrotonews.com/ $\mathrm{read} / 2014$

berkampanye keliling Indonesia, dan video berisi dukungan sejumlah tokoh dan orangorang biasa. Demikian juga dengan laman Facebook Jokowi yang disukai 3.311.213 orang, diisi dengan banyak foto dan video. Laman ini tampaknya dikelola secara rutin karena menampilkan informasi terbaru, seperti dukungan harian The Jakarta Post terhadap Jokowi yang baru disampaikan dalam editorial (Metrotv.com, 4/7/2014).

Hal yang sama dijumpai di media sosial Twitter, persaingan yang berkembang di kedua kubu adalah berupaya sekeras mungkin agar kampanye mereka menjadi trending topik dunia. Hal ini, misalnya bisa kita lihat ketika Komisi Pemilihan Umum menggelar debat antar calon presiden dan wakil presiden. Berikut perbandingan popularitas kedua
Gambar 4.

\section{Perbandingan popularitas di Facebook Fanpage dan Follower di Twitter}

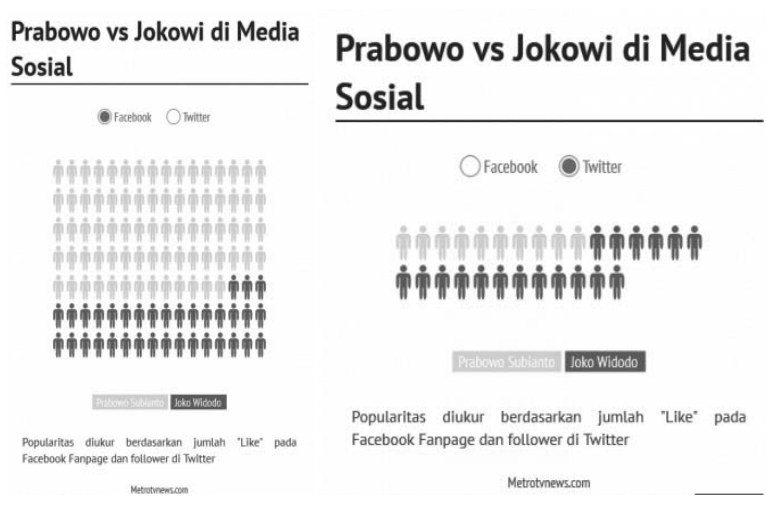

Sumber: http://teknologi.metrotonews.com/ $\mathrm{read} / 2014$

pasangan calon Presiden di media sosial yakni Facebook dan Twitter.

Penggunaan Facebook dan Twitter ketika masa kampanye kontestasi presidensial 2014, membuktikan bahwa teknologi informasi menjadi salah satu alternatif model kampanye era kekinian. Hal itu mengonfirmasi temuan lembaga pemantau sosial media yakni Awesometrics. yang memantau secara spesifik, berdasarkan sebutan atau panggilan dari masing-masing capres di media sosial, dan berdasarkan akun-akun media sosial kedua kandidat. Capres nomor urut satu, Prabowo Subianto, Awesometrics memakai keyword atau panggilan yang biasa dipakai di media sosial: prabowo, bowo, wowo, prabowow. Selain itu, capres nomor urut dua, Joko Widodo, Awesometrics memakai keyword atau panggilan yang biasa dipakai media sosial: jokowi, joko widodo, jokowow, jokower. Hasil pantauan Awesometrics, Prabowo dengan berbagai nama panggilannya sejak debat keempat 29 Juni 2014 hingga 5 Juli 2014 lebih banyak dipercakapkan di Facebook ketimbang di Twitter. Menurut data, mencapai lebih dari 107 ribu mention, sementara penyebutan Jokowi hampir 85 ribu. Sedangkan, nama-nama panggilan Jokowi lebih banyak dipakai oleh pengguna Twitter. Selama periode yang sama, penyebutan nama-nama Jokowi hampir 2 juta mention, sementara ada 1 jutaan 
lebih mention untuk penyebutan nama-nama Prabowo. Bisa dikatakan bahwa setiap jamnya, Prabowo rata-rata disebut 7500 kali, dan Jokowi rata-rata disebut 11.000 kali di media sosial. ${ }^{37}$

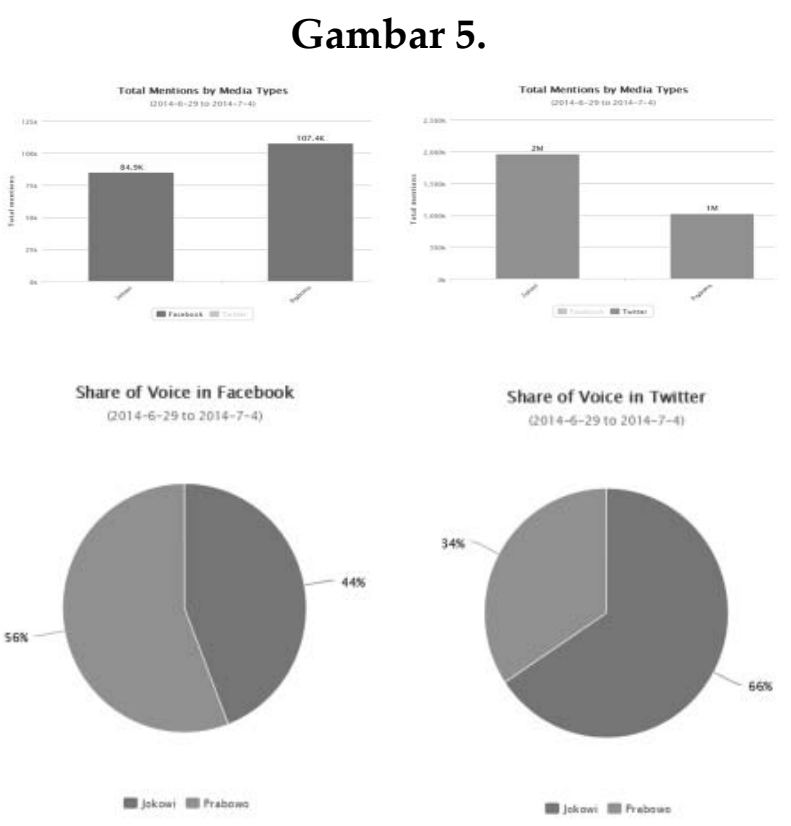

Sumber http://www.awesometrics.com

Selama periode 29 Juni hingga 4 Juli 2014, percakapan yang masuk ke akun Twitter@jokowi_ do2 aktivitasnya lebih tinggi daripada di akun @ Prabowo08. Ada hampir 400 ribu percakapan di akun @jokowi_do2, dan ada hampir 263 ribu percakapan di akun @Prabowo08. Demikian pergerakan percakapannya dari hari ke hari, perbandingan kedua akun:

\section{Jenis Kampanye Kreatif}

Jika ditelaah pada 2011 fenomena penggunaan Youtube memuncak ketika sebanyak 370 ribu video kampanye Barack Obama dan Mitt Romney dilihat oleh 2,7 miliar orang. Tidak mengherankan jika kemudian dalam kontestasi presidensial 2014, kedua kandidat calon presiden Indonesia memanfaatkan teknologi Youtube. Salah satu bentuk video yang kemudian diunggah ke

\footnotetext{
${ }^{37} \mathrm{http}$ //www.awesometrics.com/blog/yang-terpopulerdi-media-sosial-dan-yang-akunnya-teraktif-jelangkampanye-berakhir.
}

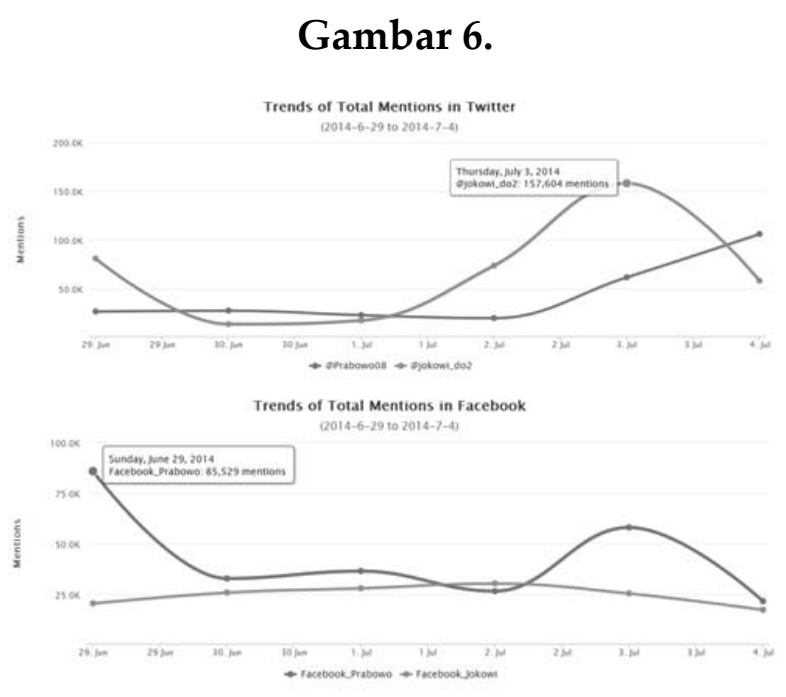

Sumber http://www.awesometrics.com

Youtube yakni aksi Marzuki Mohammad "Kill The DJ". Penyanyi kelompok musik Jogja Hip Hop Foundation ini menampilkan video berjudul Bersatu Padu Coblos No 2 yang kemudian dapat didengarkan di situs www.soundcloud.com serta diunduh secara gratis melalui situs www. mediafire. com. Begitupula dengan pendukung PrabowoHatta yang mengatasnamakan Sahabat Prabowo dengan video berjudul Happy yang kemudian juga diunggah di Youtube. ${ }^{38}$

Selain itu banyak bermunculan video yang berasal dari kaum muda seperti, JokowiJK Presiden Kita, Owl City - Good Time. Berbeda dengan video kampanye pasangan Jokowi-JK sebelumnya, video yang berisi parodi ini di upload (13/6/2014) oleh akun Fajrina Maya (@ Fajrinamaya). Dengan hanya berdurasi 3.19

\footnotetext{
${ }^{38}$ Yudha Permana, sebagai Ketua Sahabat Prabowo Jabodetabek, mengatakan, sebagian pembuatan video itu dilakukan setelah lari pagi pada hari bebas kendaraan (car free day) di Jakarta. Sebagian lagi dibuat di kantor Gerindra. Isinya tentang orang-orang yang bersukaria, tertawa-tawa, dan bermain-main. Selain di dunia maya, Sababat Prabowo juga melakukan kampanye kreatif di dunia nyata. Setiap Minggu, mereka tampil pada hari bebas kendaraan di sejumlah kota, seperti Jakarta, Riau, Bali, dan Bandung, dengan berbagai atraksi. Misalnya, lari pagi, marching band, parade, dan bagi-bagi susu disertai maskot Mas Garuda yang bentuknya komikal. Lihat, http://nasional.kompas. com/read/2014/06/08/1630474/Kampanye.Kreatif. Bermunculan.
} 


\section{Gambar 7. Video Jokowi-JK Presiden Kita, Owl City - Good Time}

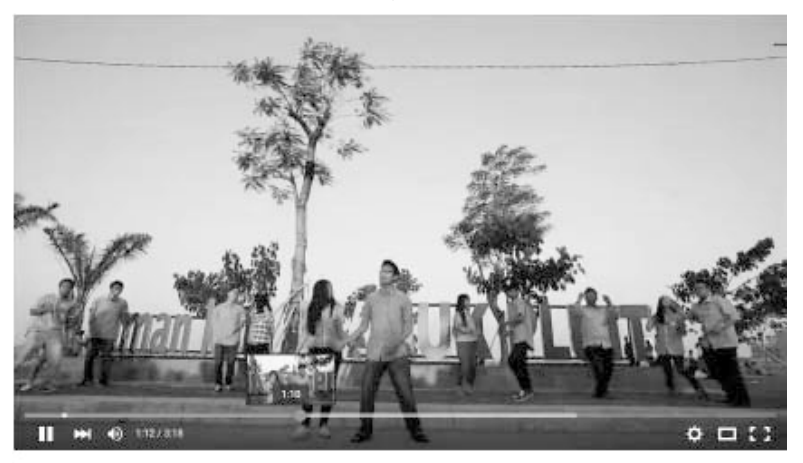

Jokowi-JK Presiden Kita, Owl City - Good Time [PARODY]

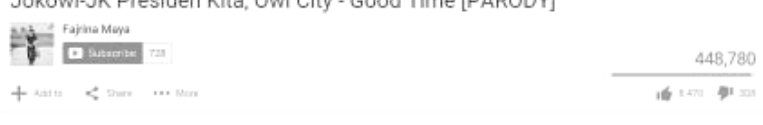

Sumber http://youtube/x5f0smH0JMM

menit video ini menjadi heboh di Youtube. Selain karena lirik lagunya yang bagus dan menggunakan nama Owl City, video klip ini memperlihatkan bahwa kaum muda juga dapat terlibat dan bergairah dalam kancah politik melalui cara-cara yang kreatif. Meski baru tiga hari diunggah atau pada tanggal 13 Juni 2014, tetapi video tersebut sudah dilihat lebih dari 30 ribu orang dan dibanjiri komentar bernada pujian. Tidak hanya itu, video ini juga masuk populer Youtube dengan kategori hiburan. ${ }^{39}$

Beragam kreativitas yang digagas oleh anak-anak muda ditujukan untuk mengajari para pemilih tentang bagaimana berpolitik yang rileks dan tidak dipenuhi kebencian. Alhasil,

\footnotetext{
${ }^{39}$ Scene awal video tersebut menceritakan seorang pemuda yang jenuh melihat perpolitikan di Indonesia, yang dipenuhi orang-orang bermental koruptif dan tidak berprestasi dibidangnya. Bahkan saat ini penyakit korupsi telah menjangkiti seluruh lembaga negara baik eksekutif, legislatif maupun yudikatif. Dalam scene berikutnya muncul beberapa anak-anak muda di pasar, perkantoran, taman yang berbicara bahwa Indonesia kedepan butuh pemimpin yang mau bekerja. Dia bisa melakukan perubahan dengan jujur, tegas, sederhana dan memiliki jiwa kepemimpinan yang merakyat. Sosok itu digambarkan melekat dalam diri Joko Widodo dan Jusuf Kalla (Jokowi-JK). Lihat, http:// pemilu.metrotvnews.com/read/2014/06/18/254091/ dukung-jokowi-jk-ini-kampanye-kreatif-pemudalewat-video-owl-city.
}

premis yang menyatakan bila kampanye kreatif dapat menjadi salah satu alternatif model kampanye politik yang dapat berperan mengubah dan mempengaruhi perilaku pemilih benar adanya. Berikut beberapa jenis kampanye kreatif yang dikenal dalam kampanye politik 2014 diantaranya;

a). Video. Selama ini rekaman pidato dan pemaparan visi-misi setiap presiden memang bisa dengan mudah kita temukan di situs Youtube. Tetapi, dengan kehadiran berbagai film pendek yang ringan atau kocak serta klip video dapat membuat pemilih terutama kaum muda lebih tertarik.

\section{Gambar 8.}

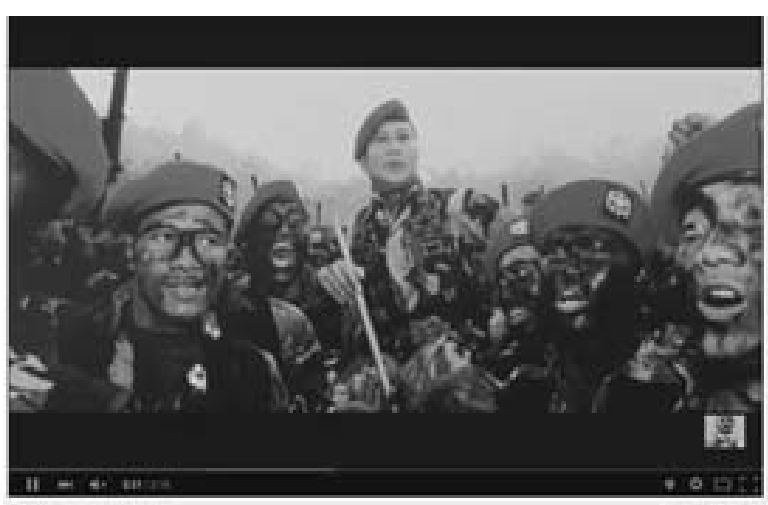

Macan Asia, Lagu Kamparne 2014 Prabowo Presidenku

Sumber: https://www.youtube.com/ watch?v=kIvhzj5k3Y0

\section{Gambar 9.}

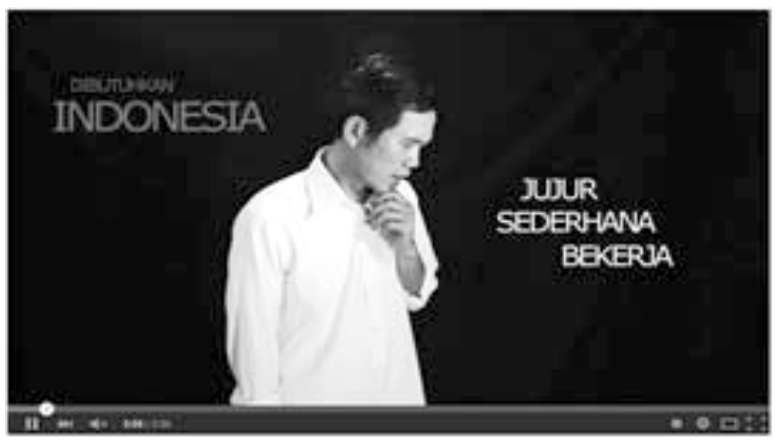

LAGU JOKOWI JK - Bersatu Padu Coblos No 2

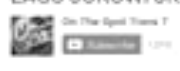

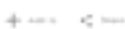

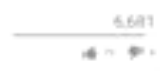

Sumber: https://www.youtube.com/ watch?v $=4 k 3 Q e 5 e l z d k$ 
b). Musik. Dukungan para musikus banyak melahirkan berbagai bentuk lagu seperti yang diciptakan oleh Marzuki "Kill the DJ". Ataupun membuat panggung musik seperti Slank dan Oppie Andaresta. Untuk materi lagu, biasanya berisi ringkasan dari visimisi para calon presiden. Di kedua kubu, terdapat seniman dan pemusik yang turut memberikan dukungan. Di kubu PrabowoHatta di kenal musisi Ahmad Dhani ${ }^{40}$ serta di kubu Jokowi-JK ada Slank, Marzuki Kill the DJ, hingga Yovie Widianto.

\section{Gambar 10.}

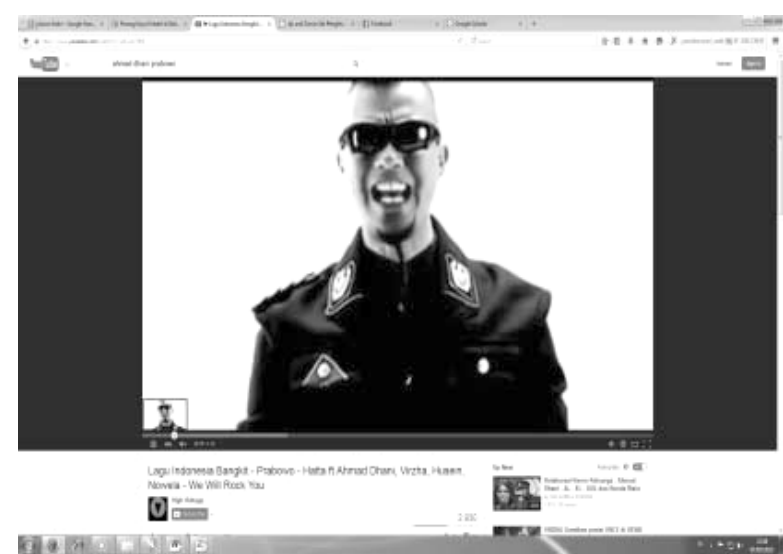

Sumber: https://www.youtube.com/ watch?v=y0LzsVJT9IE

c) Aplikasi dan Game. Untuk aplikasi dan game terdapat 60 aplikasi dan permainan di Play Store yang berkaitan dengan Jokowi, sedangkan 20 aplikasi terkait dengan Prabowo. Ada adaptasi dari permainan Candy Crush, Temple Run atau permainan sederhana seperti puzzle. Ada pula aplikasi untuk membuat wallpaper atau meme. Begitupun dengan kubu PrabowoHatta yang mengeluarkan aplikasi game

\footnotetext{
${ }^{40}$ Tetapi, ironisnya lagu kampanye yang digubah Ahmad Dhani untuk pasangan calon presiden Prabowo Subianto-Hatta Rajasa telah mencederai hakikat dari kampanye kreatif. Pasalnya, lagu tersebut tidak hanya mengundang kontroversi lantaran memakai baju militer khas Nazi Jerman, tetapi juga ilegal alias tidak mendapat izin dari si empunya lagu Brian May, gitaris Queen We Will Rock You.
}

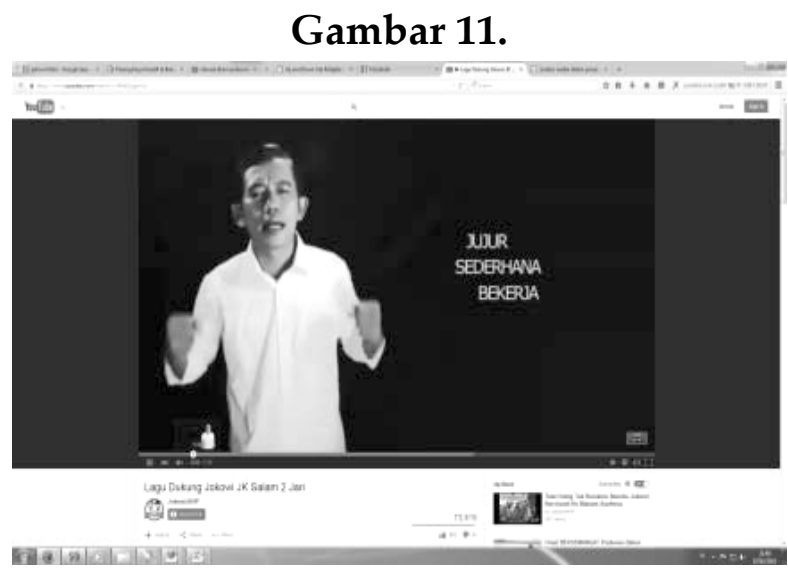

Sumber: https://www.youtube.com/ watch $?=q Q 3$ CmjglTiM

sepakbola "Garuda di Dadaku". Sedangkan di kubu Jokowi-JK, dengan dimotori oleh tim relawan Generasi Optimis, mereka memiliki game Go Jokowi.

\section{Gambar 12.}

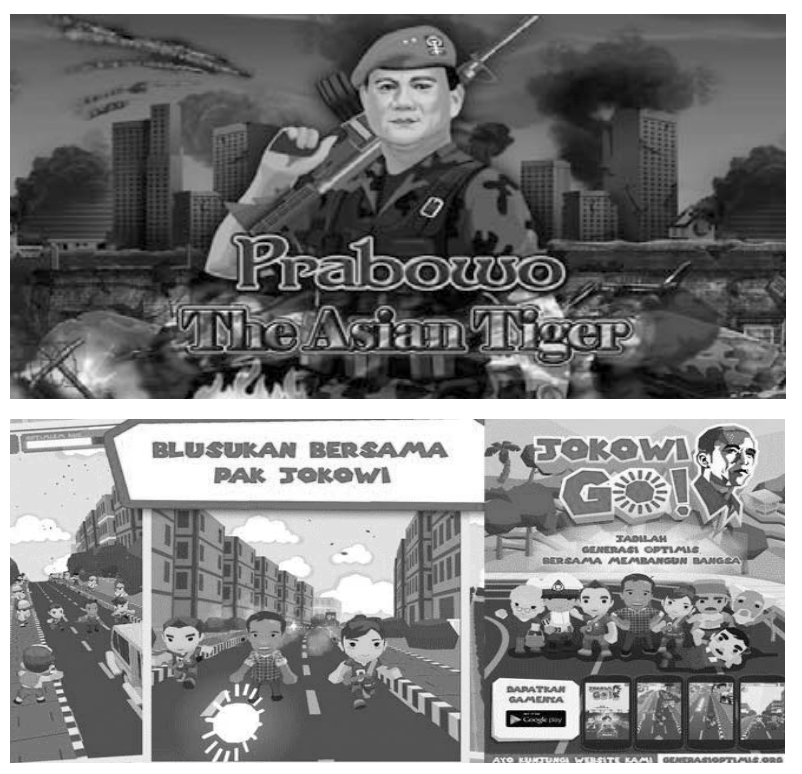

Sumber : www.genarasioptimis.org

d) Desain Visual. Bisa berwujud poster, komik, meme untuk telepon seluler, atau hal-hal lain. Biasanya, poster dan komik digarap serius oleh mereka yang memang memiliki kemampuan ilustrasi dan desain grafis yang baik. Sedangkan meme dilihat dari sejarahnya, sebenarnya meme bukanlah sesuatu yang baru ditemui 
oleh manusia, situs Knowyourmeme. com menjelaskan istilah meme (dibaca mim) sendiri telah digunakan sejak 1976. Semuanya bermula ketika seorang penulis, ahli teologi, biologi evolusioner, ilmu pengetahuan Britania Raya, Clinton Richard Dawkins menggunakan istilah meme dalam bukunya, The Selfish Gene. Dalam bukunya Dawkins menyebutkan bahwa meme adalah satuan makna kultural, seperti sebuah ide atau nilai yang diwariskan dari satu generasi ke generasi berikutnya. Pada perkembangannya, kini kita mengenal meme sebagai kumpulan potongan gambar yang diambil dari berbagai media hiburan seperti film, acara televisi, serta video musik. Potongan gambar yang sudah dipilih tersebut nantinya akan diberi tulisan yang mengangkat soal berbagai peristiwa yang terjadi saat ini dan menjadi bahan perbincangan masyarakat luas. Dan sekarang meme pun semakin berkembang seiring dengan kemajuan teknologi, meme tidak hanya dimuat dalam buku tetapi juga tampil di berbagai jejaring sosial. Menurut Lauren Ancel Meyers, seorang profesor biologi di University of Texas, meme menyebar melalui jaringan sosial online sehingga melalui media online pulalah kita mengenal berbagai macam internet meme seperti, LOLcats (gambar kucing dengan berbagai keterangan tulisan), DogShame (gambar anjing yang memakai tanda di sekitar lehernya), Crazy Frog Video dan masih banyak lagi ${ }^{41}$ bersifat amatir, karena bisa dibuat oleh siapa saja. Penggunaan desain ilustrasi yang kreatif dan menarik juga mewarnai kampanye kubu Prabowo, tentu kita ingat gambar perisai dengan ilustrasi wajah Prabowo / yang mengenakan peci di depannya sebagai bentuk simbolisasi "Perisai Kebangsaan".

${ }^{41}$ http://koran-jakarta.com/?25123-kehebohan-meme-didunia-maya
Sedangkan di pihak Jokowi, kita menemui ilustrasi yang menyerupai aksi "Tintin" karya Herge. ${ }^{42}$ Yang menampilkan "Kisah Blusukan Jokowi" ke berbagai daerah guna mendengar aspirasi rakyat. Gaya "Tintin" dipilih karena karakter "Tintin" selalu menghargai keragaman, optimisme dan perdamaian dalam masyarakat dengan menampilkan karakteristik berbagai suku, agama dan etnis. Sebut saja ketika Jokowi menjadi seorang petualang yang "blusukan" di berbagai daerah.

\section{Gambar 13.}

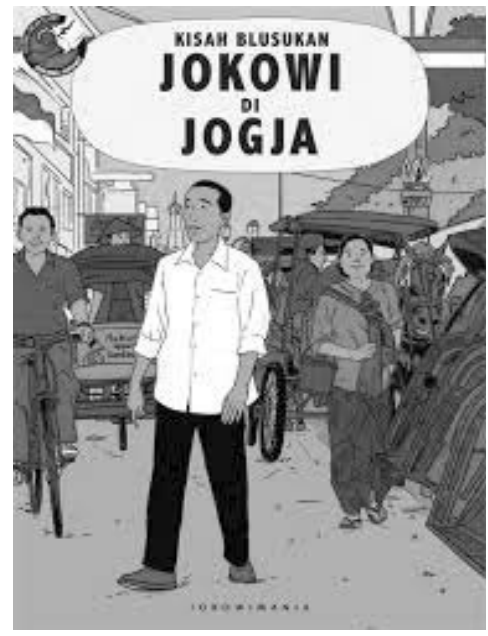

Sumber : www.gulunglenganbajumu.com

Keempat jenis kampanye kreatif yang hadir dalam kontestasi presidensial 2014 terbukti muncul dari hasil kreativitas yang digalang oleh para relawan politik. Mengutip

\footnotetext{
42 "The "Tintin style" was chosen because it's quite simple to draw digitally and manually. When we do our research about Tintin, we found that the character has a lot in common with our current president. Like many other European comic books, the main character in Tintin is an ordinary person, not a superhero, but has a strong character. Tintin is a caring character that always bolster the diversity in society, he is also an adventurous person, just like how Jokowi do his "blusukan". The lines and color of Tintin's comic book also symbolize peace, optimism, and hope - perfect to counter the other party's negative campaign". Lihat, http://www.whiteboardjournal.com/interview/21913/ ingenious-campaign-with-demokreatif.
} 


\section{Gambar 14.}

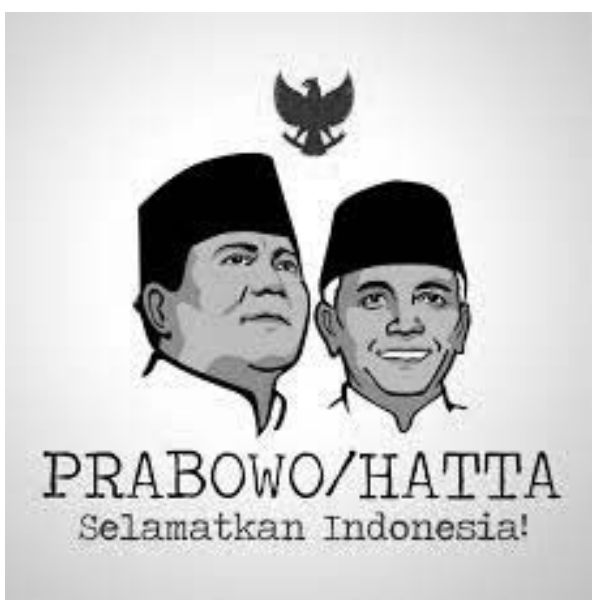

Sumber : http://www.selamatkanindonesia.com

pernyataan Koordinator relawan politik Jokowi Advanced Social Media Volunteers (JASMEV) Kartika Djoemadi, bila kehadiran berbagai jenis kampanye kreatif disebabkan adanya perubahan perilaku politik publik untuk mengantisipasi adanya serangan kampanye negatif dan hitam. Selain itu kampanye kreatif muncul sebagai bagian dari strategi pemenangan kampanye agar terlihat berbeda dengan motor pengeraknya berasal dari relawan politik. ${ }^{43}$ Perubahan perilaku politik juga dapat terlihat dari adanya jenis kampanye kreatif yang tidak memihak kedua calon presiden atau dikenal sebagai kampanye kreatif yang tidak memihak. Tujuan dibentuknya "kampanye kreatif yang tidak memihak" kepada kedua pasangan calon presiden, sebagai upaya membangun kesadaran dan pendidikan politik kepada masyarakat. Dengan tidak memihak, diharapkan dapat mengajak publik untuk tidak golput atau membenci politik. Kampanye kreatif yang tidak memihak mencoba melakukan komunikasi politik agar publik bisa lebih peduli kepada isu-isu politik dan pemerintahan tanpa harus menjadi pendukung fanatik salah satu calon presiden.

\footnotetext{
${ }^{43}$ Wawancara via Facebook dengan Kartika Djoemadi, Koordinator relawan politik Jokowi Advanced Social Media Volunteers (JASMEV) pada tanggal 22 Agustus 2015 pukul 13.49 WIB
}

Adapun beberapa contoh bentuk kampanye kreatif yang tidak memihak, diantaranya;

\section{Gambar 15. CAMEO Fun Campaign : Prabowo Jokowi}

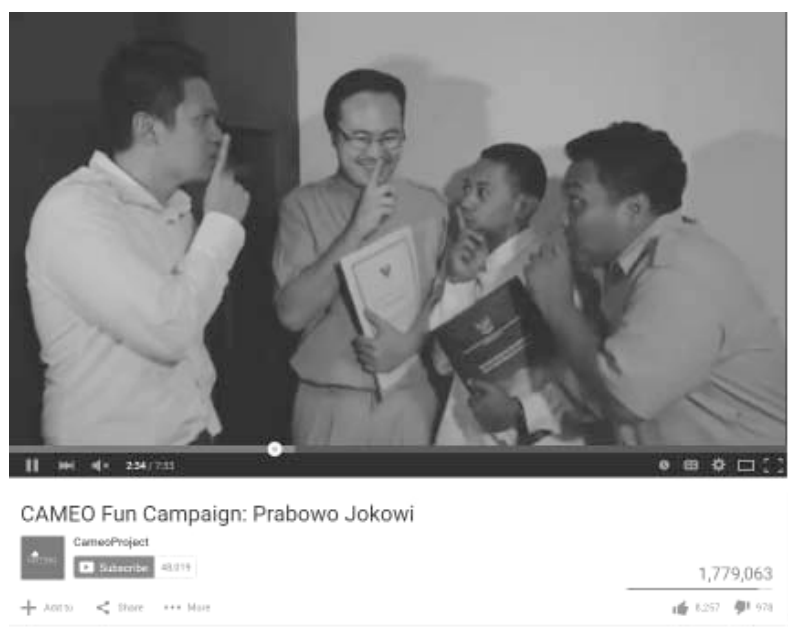

Sumber: Youtube. CAMEO Fun Campaign: Prabowo Jokowi

\section{Gambar 16. CAMEO Fun Campaign : Black VS Negative Prabowo Jokowi}

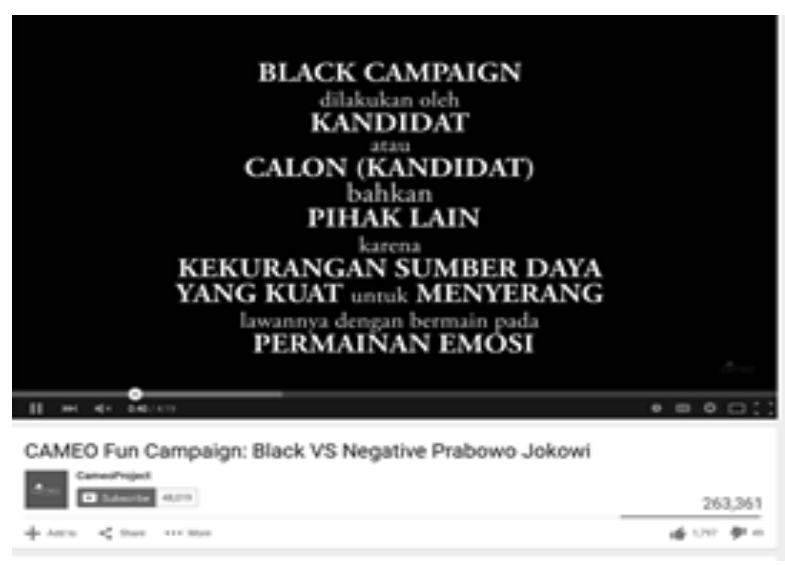

Sumber : Youtube. CAMEO Fun Campaign: Black VS Negative Prabowo Jokowi

Kedua video yang mengambarkan bentuk kampanye kreatif yang tidak memihak, pada saat diluncurkan cukup mendapat respons publik. Hal itu dapat dilihat dari respons publik. Untuk CAMEO Fun Campaign: Prabowo Jokowi, respons publik dalam dua minggu semenjak diluncurkan, sebanyak 967.157 kali tayang. Sedangkan CAMEO Fun Campaign: 
Black vs Negative Prabowo Jokowi sebanyak 18.208 kali tayang. ${ }^{44}$ Identifikasi dari kampanye kreatif yang tidak memihak dapat dikatakan sebagai wahana baru dalam upaya mendorong partisipasi publik terutama dalam memahami perihal politik dan pemerintahan.

Akhirnya, pengaruh positif pemanfaatan teknologi informasi khususnya internet dan media sosial dalam demokrasi diakui oleh Zizi A. Papacharissi, yang merujuk kesuksesan Barack Obama dalam memenangkan pemilihan umum di Amerika Serikat. Menurut, Papacharissi seolah adanya relasi mistis (mystical connection) antara teknologi dan demokrasi. ${ }^{45}$ Peran teknologi informasi sebagai saluran bagi penyampaian pesan kampanye kreatif dapat mengiring kepada hadirnya demokrasi digital. Demokrasi digital yang didefinisikan sebagai upaya menerapkan demokrasi yang berbatas waktu, ruang dan kondisi fisik lainnya dengan menggunakan peralatan digital, sebagai suatu tambahan dan bukannya praktik-praktik politik tradisional yang analog (Dijk 2006). Artinya, internet dan teknologi informasi dapat menjadi media yang efektif bagi kandidat politik untuk membangun komunikasi dan partisipasi politik secara aktif, membentuk opini dan memobilisasi dukungan secara terkoordinasi, sistematis dan interaktif. Akhirnya, kehadiran kampanye kreatif yang didukung oleh teknologi informasi menjadikan dunia digital sebagai sesuatu yang dekat, akrab dan menjadi milik publik, bukan sesuatu yang hanya dimiliki oleh mereka yang melek teknologi digital belaka (Priyono, dkk, 2014).

\footnotetext{
${ }^{44}$ Koran Tempo, Kampanye Kocak Yang Tidak Memihak. 22 Juni 2014. hlm 9

${ }^{45}$ Kajian Papacharissi berkutat pada kemampuan media untuk mentransformasi dan ditransformasi oleh relasirelasi sosial, melalui proses yang akhirnya mengubah dan memperbaruhi rutinitas sosial, ritual-ritual dan perilaku komunikatif. Lihat, Hamid, Veronica. (2014) Merancang Arah Baru Demokrasi, Indonesia Pasca Reformasi: Angin Harapan Demokrasi Digital, Nostalgia Demokrasi Klasik, Transformasi Ruang Publik dan Politisasi Media Sosial. Jakarta. Kepustakaan Populer Gramedia (KPG). hlm 728
}

\section{Membangun Kegembiraan Politik}

Jika melihat peran dan implikasi dari kemunculan kampanye kreatif, dapat disimpulkan bila kampanye kreatif dapat menjadi salah satu alternatif model kampanye modern. Pasalnya, kampanye kreatif dalam penyampaian pesan politik, mengedepankan cara-cara unik, plesetan, parodi, bahkan humor politik. Dalam konteks ini humor politik lebih bernilai daripada pesan-pesan politik yang langsung atau kadang disertai makian. Humor politik terasa lebih bergaya, berselera, dan cerdas dibanding pesan-pesan politik yang vulgar. Dengan humor, kita dapat memberikan suatu wawasan yang arif sambil tetap tampil menghibur. Humor politik juga dapat menjadi sarana persuasi untuk mempermudah masuknya informasi atau pesan yang ingin disampaikan sebagai sesuatu yang serius dan formal (Nugroho, 2014).

Kampanye kreatif dengan menggunakan materi artistik dan humor politik bisa dengan cepat menarik perhatian publik, antusiasme serta membangun model kampanye dengan suasana yang menyenangkan dan menyentuh pikiran publik. Artinya, kampanye kreatif dapat memberi ruang interaksi antara peserta kampanye dan publik tanpa rasa curiga, tanpa prasangka sehingga dapat mendorong sikap untuk berani berbeda tanpa bermusuhan. Dan pada akhirnya dapat memberikan kesempatan kepada rakyat untuk menentukan pilihannya dengan akal sehat. Dengan hadirnya kampanye kreatif telah mendorong kegembiraan politik yang jauh dari kebenciaan politik. Artinya, kegembiraan politik sebagai modal sosial, sekaligus fenomena baru demokratisasi dalam konteks ke-Indonesia-an. Kegembiraan politik ditandai dengan sekian banyaknya karya informatif yang mengandung muatan pendidikan politik seperti informasi perihal cara pencoblosan, bagaimana melakukan otokritik terhadap pemerintah hingga program kerja pemerintah. Sehingga melalui karya inovatif ini dapat memperpendek jarak antara 
rakyat dan politik. Karya informatif tersebut dimulai dari lagu yang bergenre hip hop hingga dangdut, yang berbentuk audio-visual hingga animasi. Kegembiraan semacam itulah yang kita saksikan dalam berbagai lagu yang diciptakan, baik kelompok maupun individual, mulai dari yang direkan dengan kamera canggih hingga kamera ponsel serta dinyanyikan oleh pelayan restoran hingga tukang pijat. ${ }^{46}$

Melalui kekuatan visual yang kuat dan penuh warna kegembiraan politik juga diterjemahkan dalam bentuk offline (dunia nyata), dengan menggelar sebuah pameran di galeri Salihara oleh relawan politik yang tergabung dalam kenapajokowi.com. Selama ini, kampanye politik hanya mengedepankan sloganisitik tanpa kredibilitas faktual, sehingga terkesan membosankan dan menganggu pemandangan. Ekses publik merasa jenuh dengan model kampanye konvensional yang hanya bisa menyebar fitnah dan berita bohong, terutama yang bermaterikan isu kaum minoritas serta primordialisme (suku, agama dan ras). Apalagi, selama ini penyebaran berita fitnah dan bohong dalam kampanye politik semakin menegaskan bahwa kehidupan politik Indonesia sungguh jauh dari pencerdasan dan pencerahan. Hal itu disebabkan dunia politik seringkali terbungkus oleh nalar materialisme, konsumerisme, hedonisme yang pada akhirnya melupakan nilai-nilai luhur. Padahal, bukan saatnya lagi melantunkan fitnah dan menjelekan lawan politik tanpa disertai fakta dan bukti empiris. Dengan hadirnya wacana tanpa fakta akan cepat tersingkap kepalsuan dan kebohongan dapat berdampak menggiring dunia politik seolah-

\footnotetext{
${ }^{46}$ Mulai darilagu dengan aransemen pop 80-anala Fariz RM (http://www.youtube.com/watch?v=iDEmnGcIUcQ) hingga aransemen dangdut koplo (http://www. youtube.com/watch?v=Q2dDRmKOcXc). Deskripsi ini hanya sebagian dari lagu dukungan kepada sosok Jokowi-JK yang dikumpulkan oleh Natalia Taufik. Lagu-lagu itu menunjukkan kesukarelaan rakyat untuk berpartisipasi dalam kegembiraan politik pemilu. Lihat, http://indoprogress.com/2014/06/kegembiraan-politikdan-kerja-bakti-politik/ 18 June 2014.
}

olah hanya berurusan dengan tipu-menipu, memfitnah, menjelek-jelekkan, menghalalkan cara, dan korup. Ekses hakikat politik yang merupakan perilaku untuk menyejahterakan rakyat bergeser menuju upaya mengejar harta, kekuasaan dan kemuliaan diri. Itu mengapa, publik seringkali menilai dunia politik penuh kekotoran dan jauh dari nilainilai kegembiraan.

Mencuatnya kesadaran akan pentingnya politik beretika dengan mengedepankan nilainilai kebenaran, kejujuran, dan kesantunan dalam kampanye politik merupakan makna serta substansi dari kegembiraan politik. Kegembiraan politik dipercaya dapat menumbuhkan kembali nilai-nilai keteladanan seperti musyawarah, gotong royong dan kesukarelawanan. Sehingga, kegembiraan politik mendorong lahirnya setiap orang untuk melakukan kerja-kerja politik dengan mengedepankan nilai-nilai keteladanan yang sekaligus menjadi modal kuat bagi bangsa Indonesia untuk menghadapi berbagai persoalan di tengah persaingan global yang ketat. Namun, syarat utama dalam menggerakkan kegembiraan politik adalah dengan menggiring roda kemajuan bangsa ke ranah etika politik yang mengutamakan kesejahteraan rakyat di atas segala-galanya. Sehingga, publik dapat kembali menemukan keceriaan dalam bersentuhan dengan politik. Artinya, melalui kampanye kreatif diharapkan politik dapat kembali menemukan keindahan dan kehormatannya. Sebagaimana kata Aristoteles, politik itu semestinya indah dan terhormat, yakni sebagai wahana membangun masyarakat yang kesejahteraan rakyat dapat tercipta oleh kehidupan politik yang beretika.

Kehadiran kampanye kreatif sebagai model kampanyemodern yang mengedepankan etika dan moralitas politik dapat menjadi momentum kelahiran kegembiraan politik rakyat Indonesia. Kegembiraan politik yang dimaksudkan adalah mengembalikan tujuan luhur dan kesucian politik guna memberikan 
pencerahan dan mengarahkan masyarakat ke hidup yang lebih baik dengan penuh pengorbanan, dan bukan hanya berhenti pada kalkulasi untung-rugi semata. ${ }^{47}$ Kegembiraan politik, adalah antitesa sebuah situasi di mana publik selama ini menganggap politik penuh dan sarat dengan intrik, tipu muslihat dan ajang perebutan kekuasaan. Kegembiraan itu muncul dari partisipasi politik itu sendiri, bukan dari tawaran uang atau politik balas jasa. Kegembiraan yang lahir dari kreativitas berkomunikasi yang kemudian menyadarkan kita tidak semuanya harus dibayar dengan uang. ${ }^{48}$ Kegembiraan ini muncul dari pengertian bahwa rakyat berperan serta dan memegang kendali politik. BahkanSehingga rakyat dapat memiliki kedaulatan politik untuk mewujudkan kedaulatan itu dalam pilihan ideologisnya. Dengan berlandaskan sebagai manusia yang berbudaya, kampanye kreatif dipercaya mampu melahirkan demokrasi yang berbudaya, yakni pesta demokrasi yang menyenangkan dan menghibur.

\section{Kesimpulan}

Merujuk pada kontestasi presidensial 2014, kampanye politik tetap dipenuhi oleh geliat kampanye hitam yang bertujuan melemparkan isu, gosip politik. Mengutip Stein dalam (Don F. Faules, 1998 : 200), gosip politik diistilahkan grapevine, yakni metode pemberian sebuah laporan rahasia dari orang ke orang yang tidak dapat diperoleh melalui saluran biasa, karena isi pesan grapevine senantiasa diwacanakan ke publik melalui komunikasi informal (face to face communication). Di mana akhirnya diamplifikasi media melalui bungkus pemberitaan yang samar-samar, sehingga dengan kultur rakyat Indonesia yang lebih cepat menerima isu politik ketimbang pesan melalui tulisan, menjadikan penentu merebaknya

\footnotetext{
${ }^{47}$ Arianto, Bambang (2015). Pilkada dan Kegembiraan Politik. Tribun Jogja. Edisi 1 September

${ }^{48} \mathrm{Ibid}, \mathrm{hlm} 184$.
}

grapevine. Padahal pesan grapevine kerapkali dijadikan ajang character assasination figur politik. Gosip politik yang berkembang dewasa saat ini masih di ambang batas kewajaran, namun menjadi tidak wajar bila hal tersebut seringkali terjadi dalam proses persidangan korupsi politik yang dimanfaatkan untuk menarik keterlibatan pihak lain yang belum terbukti didepan hukum. Artinya gelagat gosip politik yang ditimbulkan masih bersifat asumsi dan terhendus sebagai aroma politik, yang tujuannya menjatuhkan lawan politik, kelompok bahkan partai politik. Situasi seperti ini sangat rawan terjadinya penyalahgunaan gosip politik. Ketatnya persaingan antar elite samar-samar namun pasti telah menjadikan gosip politik sebagai bumper politik sebagai bekal menjatuhkan lawan politik. Gosip politik dapat menggelinding menjadi kepentingan dan faksionalisasi politik yang akhirnya dapat dikomodifikasi menjadi alat pengembos elektoral lawan politik. Akhirnya, publik akan disuguhi permainan politik secara terbuka, destruktif dan terkesan rendahan. ${ }^{49}$ dan sejenisnya tanpa didukung fakta atau bukti. Dalam sejarahnya perkembangan kampanye hitam telah bermunculan pada era Orde Baru. Sedangkan, pasca pemerintahan Presiden Soeharto, kemunculan kampanye hitam semakin mendapat tempat, seiring tingginya kebebasan berpendapat. Merebaknya kampanye hitam juga ditunjang oleh kondisi immoralitas dan mistifikasi (mitologis) yang masih bercokol dalam benak publik. Budaya feodalisme dan paternalistik yang begitu kental menjadi faktor penunjang bercokolnya kampanye hitam dalam demokrasi Indonesia. Immoralitas merupakan kecederungan hilangnya prinsip moral dalam benak publik yang tergantikan dengan permainan moral yang ditandai dengan lenyapnya rasa malu. Sedangkan mistifikasi atau mitologisasi

\footnotetext{
${ }^{49}$ Arianto, Bambang. (2014). Gosip Politik dan Pilpres 2014. Koran Tempo. Edisi 8 Januari
} 
seringkali mendominasi ruang publik yang terkadang tidak logis dan menyesatkan. ${ }^{50}$ Itu mengapa, saat kampanye politik berlangsung isu-isu yang bertebaran lebih banyak diisi materi yang berbau mitos politik. $\mathrm{M}$ i t o s politik memang tidak pernah lepas dari politik atau kekuasaan, demikian pula sebaliknya politik tidak pernah lepas dari mitos. Bahkan sudah lazim di kalangan yang paham tentang dunia pencitraan, mitos memiliki daya hipnotis yang luar biasa. Sebenarnya mitos berawal dari penciptaan simbol yang lantas mengalami sakralisasi. Sakralitas sebuah simbol yang dibumbui dengan doktrin-doktrin merupakan penyederhanaan dari suatu ideologi. Simbol, mitos, doktrin dan ideologi adalah perangkat yang bahkan wajib ada dalam politik, baik politik personal maupun kelompok. ${ }^{51}$ Beruntung kehadiran model kampanye kreatif setidaknya telah mampu mengimbangi peredaran kampanye hitam terutama di masyarakat kelas menengah, sehingga peredaran kampanye hitam tidak begitu berjalan maksimal dilapisan masyarakat. Meski demikian, di kalangan masyarakat kelas terbawah berbagai materi kampanye hitam dapat mempengaruhi pola pikir masyarakat. Hal itu terbukti, ketika kontestasi presidensial 2014, publik digemparkan oleh kehadiran kampanye hitam melalui tabloid bertajuk Obor Rakyat. ${ }^{52}$ Kemunculan tabloid Obor Rakyat disadari tidak lepas dari adanya kekuatan media dalam upaya membentuk realitas sosial. Ketika realitas media menyerupai realitas sosial, proses resonansi itu berlaku yang kemudian menjadikan media sebagai alat manipulasi opini publik. Tabloid Obor Rakyat bukan saja merupakan distorsi politik media

\footnotetext{
${ }^{50}$ Kurniawan, Robi Cahyadi. (2009). Kampanye Politik: Idealitas dan Tantangan. Jurnal Ilmu Sosial dan Ilmu Politik. Vol. 12, No. 3 Edisi Maret.

${ }^{51}$ Arianto, Bambang (2014). Parpol dan Mitos Politik. Harian Kedaulatan Rakyat. Edisi 7 Februari.

${ }^{52}$ Sudibyo, Agus. (2014). Obor Rakyat dan Residu Demokrasi. Harian Kompas. Edisi 17 Juni.
}

namun lebih dari itu, telah memerankan diri dengan sejumlah teknik propaganda yang ada dalam rubrik yang dimilikinya. Eksesnya, ruang publik semakin disesaki oleh berita dan propaganda bohong yang membuat politik semakin jenuh. Oleh sebab itu, diperlukan kampanye yang dapat didesain dengan baik melalui gagasan (program) agar tampak rasional, akuntabel, dan berdaya pikat.

Kehadiran kampanye kreatif terbukti dapat menepis kejenuhan publik dalam menyaksikan model kampanye politik yang kian hari kian membosankan, termasuk menangkal penyebaran kampanye yang hanya mengarah kepada hal-hal yang tidak substansial. Hal itu didasarkan beberapa kelemahan yang dimiliki kampanye hitam. Pertama, Sumber informasi tergolong gelap, sehingga kredibilitasnya samar-samar dan substansi diragukan kebenarannya. Padahal kredibilitas adalah kunci utama keberhasilan kampanye hitam. Bahkan, menurut Becker (1958) kampanye hitam sejatinya harus berdasarkan data intelijen yang akurat, tepat serta didukung oleh hasil evaluasi yang terpercaya.Kedua, Ajakan, persuasi, dan informasi dalam kampenye hitam yang menyerang personalitas Jokowi nyatanya gagal dan tidak terbukti mampu membangkitkan emosi publik. Padahal, salah satu pra-syarat efektivitas kampanye hitam ialah bagaimana kemampuan dari sebuah anjuran mampu membangkitkan emosi publik dan kebencian terhadap obyek yang memang menjadi sasaran (Fraser, 1957). ${ }^{53}$ Lagipula teknik yang digunakan adalah penerapan nilai-nilai seni yang membuat teknik penyampaian lebih terasa ringan dan tidak monoton. Sebab, seni dapat menjadi salah satu alat untuk menyampaikan pesan politik yang mudah beradaptasi dengan nalar publik. Oleh karena itu sinergisitas seni dan politik, dapat memberikan kita wawasan yang arif

53 Arianto, Bambang. (2014). Kegagalan Kampanye Hitam. Harian Kedaulatan Rakyat. Edisi 23 Juni. 
sambil tetap tampil menghibur terutama dalam urusan politik dan pemerintahan. Alhasil, sinergi antara seni dan politik menjadi sarana persuasi untuk mempermudah masuknya informasi atau pesan politik yang ingin disampaikan sebagai sesuatu yang serius dan formal. ${ }^{54}$ Artinya, kampanye kreatif dapat mewujud dalam penanda kata, konstruksi gagasan, konseptualisasi penanganan masalah, serta teknik dan strategi yang inspiratif.

Dengan demikian, kampanye kreatif telah mampu menghipnotis pemilih dengan diksi dan pemilihan tema yang menarik, luwes, mudah dimengerti, jenaka dan tidak membosankan. Selain itu kampanye kreatif juga mampu menampilkan visualisasi yang sangat menarik, kreatf, menawan serta tidak membosankan. Dengan pemilihan konsep yang bagus dapat menggerakkan minat berpartisipasi dalam politik dan menumbuhkan kesadaran berpolitik bagi publik. Kampanye kreatif seolah menjadi alat transformasi yang memiliki titik simpul gagasan besar, yang berbasis pendekatan komunitarian. Dikarenakan, kampanye kreatif dapat membangun komunikasi yang inspiratif langsung ke sasaran pemilih, sekaligus menjadi sebuah metode kampanye yang berorientasi pada pemberdayaan jangka panjang, terutama dalam proses untuk transfer pendidikan politik. Sehingga dimasa mendatang pemilih akan tetap dapat tumbuh dengan kesadaran yang kuat terhadap dinamika politik dan pemerintahan.

Sejatinya, kampanye kreatif yang mengedepankan kreativitas dapat dijadikan rujukan bersama bagi para kandidat politik dalam ritual kontestasi politik, sehingga prosesi kampanye politik dapat mewujud dalam bentuk yang lebih populis dan mudah dimengerti publik. Sudah saatnya para kandidat politik dapat menggunakan kampanye dengan pendekatan modern, yang menarik, unik dan

\footnotetext{
. (2015). Menyoal Sinergistas Seni dan Politik. Harian Kedaulatan Rakyat. Edisi, 31 Juli.
}

tentunya berbasis literasi politik. Jika hal itu terlaksana, kampanye kreatif dapat mendorong kelahiran demokrasi partisipatoris yang diartikan sebagai demokrasi yang melibatkan seluruh masyarakat dalam proses politik dan pengambilan keputusan publik, baik langsung maupun tidak langsung, di mana rakyat dapat mengajukan usul, masukan mengenai kebijakan yang akan ditetapkan oleh pemerintah. Apalagi dalam konteks ini, publik dan relawan politik merupakan aktor utama dalam upaya membangun kegembiraan politik.

Tetapi harus dipahami bersama, bahwa kampanye kreatif bukanlah ajang untuk membentuk hiperealitas ${ }^{55}$ melainkan memberi kesempatan kepada publik untuk mengetahui platform, komitmen, kredibilitas, program kerja dan orientasi masa depan kandidat politik. Meski demikian, harus dipahami bersama, bahwa kampanye kreatif sangat bergantung pada sosok figur dan ketokohan. ${ }^{56} \mathrm{Hal}$ itu disebabkan daya tarik figur sangat berperan menarik hadirnya partisipasi publik terutama para relawan politik yang memiliki jiwajiwa kreatif ${ }^{57}$ dalam ritus kontestasi politik

\footnotetext{
${ }^{55}$ Semenjak sistem pemilu langsung, survei menjadi alat kampanye terselubung para kandidat dalam upaya membangun popularitas klien layaknya tanpa dibingkai dengan obyektifitas. Hiperrealitas dibangun dari mendesain, mereduksi, memutarbalikkan fakta sesuai pesanan klien. Cara-cara seperti nantinya akan mencederai perilaku pemilih dan menjadi penyebab mandulnya sensibilitas publik. Lihat, Arianto, Bambang (2013). Politik Ilusi Popularitas. Harian Solo Pos, Edisi 16 November.

${ }^{56}$ Faktor figur sangat mempengaruhi, sebab, para pegiat seni ini tidak akan mau melakukan kampanye kreatif jika bukan untuk mendukung sosok Jokowi. Artinya ini murni mendukung Jokowi. Jikalau saja ini untuk pemilu atau calon presidein yang lain, tidak akan ada pembicaraan soal kampanye kreatif. Lihat, Prast, dkk. (2014). Demokreatif. Kepustakaan Populer Gramedia. hlm 19

${ }^{57}$ Jokowi mengungkapkan, sejumlah gagasan kreatif yang dituangkan dalam kampanye itu menunjukkan bahwa industri kreatif yang kebanyakan ditopang anak-anak muda memiliki pasar yang prospektif. "Komik di luar negeri banyak yang dibuat oleh kita. Itu yang mau kita angkat. Kita ingin menunjukkan industri kreatif yang
} 
baik nasional maupun lokal. Singkat kata, kehadiran kampanye kreatif diharapkan dapat segera menyadarkan publik sebagai determinan utama demos untuk dapat bahu membahu mengembalikan politik Indonesia dalam kesejatiannya yang luhur, terhormat dan tentunya penuh nilai-nilai keteladanan. Walhasil, kemunculan kampanye kreatif dalam kontestasi presidensial 2014, sebagai bukti bila bangsa ini telah berhasil menjadikan ritual kontestasi politik lebih menarik, asyik dan menghibur.

\section{Daftar Pustaka}

Adian, Donny Gahral. (2012). Personalisasi Politik. Kompas. Edisi 27 September.

Adhistrisna, Yoga, dkk (2015). Kampanye 2.0 - Voter Generated Content. Jakarta: Kepustakaan Populer Gramedia.

Arianto, Bambang. (2014). Fenomena Relawan Politik Dalam Kontestasi Presidensial 2014. Jurnal Ilmu Sosial dan Ilmu Politik. Vol. 18 No. 2 Edisi November. 12 Maret 2015. Jokowisme.

Harian Bernas.

. 23 Juni 2015. Kegagalan

Kampanye Hitam. Harian Kedaulatan Rakyat.

30 Juni 2015. Menyoal

Sinergisitas Seni dan Politik. Harian Kedaulatan Rakyat. . 8 Januari 2014. Gosip Politik

dan Pilpres 2014. Koran Tempo. . 1 Januari 2015. Pilkada dan

Kegembiraan Politik. Tribun Jogja. . 16 November 2013. Politik

Ilusi Popularitas. Solo Pos.

Adiputra, Wisnu Martha. (2014). Sinopsis Fisipol's Research Days 2014: Siberaktivisme dalam Komunikasi Politik Pemilihan Umum 2014. Yogyakarta: Fisipol UGM.

dimotori anak muda punya pasar, tetapi belum diberi ruang untuk perhatian. Lihat, http://nasional.kompas. com/read/2014/06/08/1630474/Kampanye.Kreatif. Bermunculan.
Blumenthal. S. (1982). The Permanent Campaign. New York. Simon and Schuster.

Dijk, Jan AGM va (2006). The Newwork of Society: Social Aspects of New Media, second edition. London and California: Sage Publication

Danial, Akhmad. (2009). Iklan Politik Televisi, Modernisasi Kampanye Politik Pasca Orde Baru. Yogyakarta: Penerbit LKIS.

Dominick, Joseph., Messere, Fritz., \& Sherman, Barry L. (2004). Broadcasting, Cable, The Internet, and Beyond: An Introduction To Modern Electronic Media. New York: McGraw Hill.

Firmanzah. (2012). Marketing Politik, Antara Pemahaman dan Realitas. Jakarta: Yayasan Pustaka Obor Indonesia.

Gelman, Andrew \& King, Gary. (1993). Why are American presidential election polls sovariable when are so predictable. British Journal of Political Science. Vol. 23

Hamid, Veronica. (2014) Merancang Arah Baru Demokrasi, Indonesia Pasca Reformasi: Angin Harapan Demokrasi Digital, Nostalgia Demokrasi Klasik, Transformasi Ruang Publik dan Politisasi Media Sosial. Jakarta: Kepustakaan Populer Gramedia.

Habermas, Jurgen. (1989). Ruang Publik, Sebuah Kajian Tentang Kategori Masyarakat Borjuis. Yogyakarta: Kreasi Wacana.

Hill, David T \& Sen Krishna. (2005). The Internet in Indonesia \& New Democracy. London and New York: Routledge.

Hardiman, F Budiman. (2010). Ruang Publik, Melacak Partisipasi Demokratis dari Polis sampai Cyberspace. Yogyakarta: Penerbit Kanisius.

Irkham, M Agus. 19 Desember 2014. Jonru. Koran Tempo.

Kurniawan, Robi Cahyadi. (2009). Kampanye Politik: Idealitas dan Tantangan. Jurnal Ilmu Sosial dan Ilmu Politik Fisipol. Vol. 12 No. 3 Edisi Maret.

Liddle, R William. (1992). Pemilu-Pemilu Orde Baru; Pasang Surut Kekuasaan Politik. Jakarta: LP3ES. 
Lock. A \& Harris, P. (1996). Political Marketing Vive La Difference. European Journal of Marketing. Vol 30 No. 10/11 Juni 1996

Prasetyo, Hari, dkk. (2014). Demokreatif, Kisah Blusukan Jokowi. Jakarta: Kepustakaan Populer Gramedia.

Priyono, AE, dkk. (2014). Media Sosial Alat Gerakan Sipil; Belajar dari Suksesi Jakarta dan Masa Depan Indonesia. Jakarta: Public Virtue Institute.

Pfau, Michael dan Roxanne Parrot. (1993). Persuasive Communication Campaign, Massachussets. Allyn dan Bacon.

Nyarwi, (2009). Golput Pasca Orde Baru: Merekonstruksi Ulang Dua Perspektif. Jurnal Ilmu Sosial dan Ilmu Politik. Vol. 12 No.3 Edisi Maret.

Nugroho, Kelik M. 6 Januari 2014. Humor Politik. Koran Tempo.

Scammel, Margaret. (1997). The Wisdom of the War Room: U.S Campaigning and Americanization, Research Paper R-17, dalam The President and Fellows of Harvard College. Edisi April, hlm. 3.

Sembiring, Bellisa G. (2014). Media Baru dan Kampanye Politik: Studi Kasus Strategi Komunikasi Politik menggunakan Media Baru oleh Jokowi Ahok Social Media Volunteers (JASMEV) Pada Pilkada DKI Jakarta Bulan Agustus September 2012. Fisipol UGM: Skripsi Jurusan Ilmu Komunikasi (tidak dipublikasikan).

Schenk, Michael \& Thomas Dobler. (2002). Towards a Theory of Campaigns: The Role of Opinión Leaders. Dalam Klingemann \& Rommele. 2002. Public Information Campaigns $\mathcal{E}$ Opinión Research. Thousand Oaks: Sage Publications.

T. Yeremias Keban, (1998). Cara Pengukuran Variabel Penelitian. Yogyakarta: Gama Press.

\section{Internet}

Savirani, Amalinda (2015). Jokowi's supporters are starting to doubt the Indonesian Obama.
(Online). (http://theconversation.com/ jokowis-supporters-are-starting-to-doubtthe-indonesian-obama-37843, diakses 18 Mei 2015)

Suryajaya, Martin (2014). Kegembiraan Politik dan Kerja Bakti Politik. (Online). http:// indoprogress.com/2014/06/kegembiraanpolitik-dan-kerja-bakti-politik/18 June 2014, diakses 25 Juni 2015)

Awesometrics.com. (2014). Yang Terpopuler di Media Sosial dan Yang Akunnya TeraktifJelang Kampanye Berakhir (Online). (http://www. awesometrics.com/blog/yang-terpopulerdi-media-sosial-dan-yang-akunnyateraktif-jelang-kampanye-berakhir, diakses 17 Agustus 2015)

Endosia.com. (2014). Fenomena I Stand on The Right Side: Perang Senyap Pita Dukungan Capres. (Online). (http:// w w w.endonesia.com/2014/06/ fenomena-i-stand-on-right-side-perang. html? show Comment $=1420936581930$, diakses 25 Mei 2015).

Duniaku.net. (2014). Jokowi Go! Kampanye Kreatif dari Generasi Optimis Berhasil Tembus Top RankGooglePlayStore.(Online). (http://www.duniaku.net/2014/06/30/ jokowi-go-kampanye-kreatif-dari-generasioptimis-berhasil-tembus-top-rank-googleplay-store, diakses, 18 September 2015)

Fanspage-id.com. (2012). Menggalangdukungan-di-media-sosial.html. (Online) (http://www.fanspage-id.com/2012/10/ menggalang-dukungan-di-media-sosial. html, diakses, 16 Agustus 2015)

Gulungkenganbajumu.com. (2014). (Online). (http://gulunglenganbajumu.com, diakses 3 Juli 2015)

Indopos.co.id. (2014). Kampanye Kreatif ala Jokowi. (Online). http://www.indopos. co.id/2014/06/kampanye-kreatif-ala-jokowi. html, diakses 25 Mei 2015)

Kompas. (2014). Kampanye Kreatif Bermunculan. (Online). (http://nasional.kompas.com/ $\mathrm{read} / 2014 / 06 / 08 / 1630474 /$ Kampanye. 
Kreatif.Bermunculan, diakses 30 Juni 2015)

Koran Jakarta (2014) Kehebohan Meme di Dunia Maya. (Online). (http://koran-jakarta. com/?25123-kehebohan-meme-di-duniamaya, diakses 17 Agustus 2015)

Selamatkan Indonesia.com. (2014). http:// www.selamatkanindonesia.com, diakses 17 Agustus 2015

LSI. (2014). Kampanye Negatif dan Prediksi Hasil Pileg 2014. (Online). (http://1si.co.id/ 1si/2014/04/02/kampanye-negatif-danprediksi-hasil-pileg-2014, diakses 30 Juni 2015)

Metrotvnews. (2014). Kampanye Politik di Media Sosial: Prabowo vs Jokowi. (Online). (http://teknologi.metrotvnews.com/ $\mathrm{read} / 2014 / 07 / 04 / 261288 /$ peran-mediasosial-dalam-kampanye-politik, diakses 31 Mei 2015)

. (2014). Dukung Jokowi-JK, Ini

Kampanye Kreatif Pemuda Lewat Video 'Owl City'. (Online). (http://pemilu.metrotvnews. com/read/2014/06/18/254091/dukungjokowi-jk-ini-kampanye kreatif-pemudalewat-video-owl-city, diakses 25 Mei 2015)

Republika. (2014). Pilpres 2014 Hasilkan Banyak Kampanye Kreatif. (Online). (http://www. republika.co.id/berita/pemilu/beritapemilu/14/07/23/n958et-pilpres-2014hasilkan-banyak kampanye-kreatif, diakses pada 15 Juni 2015)

The Conversation. (2015). Jokowi's supporters are starting to doubt the "Indonesian Obama". (Online). (http://theconversation. com/jokowis-supporters-are-startingto-doubt-the-indonesian-obama-37843, diakses 18 Mei 2015)

Viva.co.id. (2014). Angka Golput Menurun di Pemilu 2014. (Online). (http://politik.news. viva.co.id/news/read/503322-angka-golput- menurun-di-pemilu-2014, diakses 15 Juni 2015)

Viva.co.id. (2014). 15 Artis Lolos Jadi Anggota DPR RI 2014-2019. (Online). (http://politik. news.viva.co.id/news/read/504521-15-artislolos-jadi-anggota-dpr-ri-2014-2019, diakses 20 September 2015)

Whiteboardjournal.com. (2015) Ingenious campaign withdemokreatif. (Online) (http://www.whiteboardjournal.com/ interview/21913/ingenious-campaign-withdemokreatif/, diakses 2 Juli 2015)

Youtube. (2014). Macan Asia Lahu kampanye 2014 Prabowo Presidenku. (Online). (https://www. youtube.com/watch?v=kIvhzj5k3Y0)

Youtube. (2014). Lagu Jokowi-JK Bersatu padu Coblos Nomor 2. (Online). (https://www. youtube.com/watch?v=4k3Qe5elzdk)

Youtube. (2014). Jokowi-JK Presiden Kita, Owl City - Good Time. (Online). (http://www. youtube/x5f0smH0JMM)

Youtube. (2014). Lagu Indonesia Bangkit. (Online). (http://www.youtube.com/ watch?v=y0LzsVJT9IE)

Youtube. (2014). CAMEO Fun Campaign: Prabowo Jokowi (Online). (https://www. youtube.com/watch? $\mathrm{v}=$ hITLHh0flPo, diakses 25 Mei 2015)

Youtube. (2014). CAMEO Fun Campaign : Black VS Negative Prabowo Jokowi. (Online). (https:// www.youtube.com/watch? $\mathrm{v}=1 \mathrm{~s} 2 \mathrm{Flsr} 9 \mathrm{cMs}$ )

\section{Wawancara}

Wawancara dengan Kartika Djoemadi, Koordinator relawan politik Jokowi Advanced Social

Media Volunteers (JASMEV), tanggal 22 Agustus 2015 pukul 13.49 WIB

Wawancara dengan Hari Prasetyo, relawan politik Demokreatif, tanggal 11 Oktober 2015 pukul 16.00 WIB 